\title{
Review
}

\section{The positive contribution of invertebrates to sustainable agriculture and food security}

\author{
Matthew J.W. Cock ${ }^{1}$, Jacobus C. Biesmeijer ${ }^{2}$, Raymond J.C. Cannon ${ }^{3}$, Philippa J. Gerard ${ }^{4}$, \\ Dave Gillespie ${ }^{5}$, Juan J. Jiménez ${ }^{6}$, Patrick M. Lavelle ${ }^{7}$ and Suresh K. Raina ${ }^{8}$
}

Address: ${ }^{1}$ c/o CABI Europe - UK, Bakeham Lane, Egham TW20 9TY, UK. ${ }^{2}$ NCB Naturalis, PO Box 9517,2300 RA Leiden, The Netherlands. ${ }^{3}$ The Food and Environment Research Agency, Sand Hutton, York YO41 1LZ, UK. ${ }^{4}$ AgResearch Ltd, Ruakura Research Centre, PO BOX 3123, Hamilton 3240, New Zealand. ${ }^{5}$ Research Centre, Agassiz, Agriculture and Agri-Food Canada, P.O. Box 1000, Agassiz, BC VOM 1A0, Canada. ${ }^{6}$ ARAID, Instituto Pirenaico de Ecología (IPE), Consejo Superior de Investigaciones Científicas (CSIC), Avda. Llano de la Victoria s/n, Apdo. 64, Jaca 22700, Huesca, Spain. ${ }^{7}$ Institut de Recherche sur le Développement, Centro Internacional de Agricultura Tropical TSBF Institute, Cali, Colombia. ${ }^{8}$ icipe - African Insect Science for Food and Health, PO Box 30772-00100, Nairobi, Kenya.

AQI Correspondence:

$\begin{array}{ll}\text { Received: } & 14 \text { May } 2012 \\ \text { Accepted: } & 18 \text { June } 2012\end{array}$

doi: 10.1079/PAVSNNR20127043

The electronic version of this article is the definitive one. It is located here: http://www.cabi.org/cabreviews

(C) CAB International 2012 (Online ISSN 1749-8848)

\section{Abstract}

This study focuses on three main groups of organisms: soil invertebrates, biological control agents (BCAs) and pollinators. These groups play key roles in agricultural systems, and have the potential to be used, moved or manipulated for the benefit of agriculture. Soil invertebrates are a key component of agricultural landscapes. They participate in essential soil processes that maintain healthy productive soils in the face of changing environmental conditions. Reducing the diversity of a community of soil invertebrates reduces its beneficial functions and services, with drastic ecological effects such as long-term deterioration of soil fertility and agricultural productive capacity. The introduction of a keystone species may have detrimental or beneficial effects depending on the context. The interaction between soil invertebrates and soil microorganisms is critical: the activities of soil invertebrates regulate microbial activity in soils, and micro-organisms enter into intimate relationships with soil invertebrates to help them degrade highly complex compounds such as cellulose. Different groups of invertebrates provide biological control of crop pests. In many situations, they form the basis of, and tools for, the integrated pest management (IPM) approach. Given that the losses caused by pre- and post-harvest pests can be very substantial, the potential benefits of using invertebrates as BCAs are vast, but as yet only partially tapped. The potential for soil invertebrates to assist in this function is still largely unknown. Pollination services by animals, especially by insects, are among the most widespread and important processes that structure ecological communities in both natural and agricultural landscapes. An estimated $\mathbf{6 0 - 9 0 \%}$ of the world's flowering plants - including a range of economically important species - depend on insects for pollination. Crop pollination used to be (and often still is) provided by wild pollinators spilling over from natural and semi-natural habitats close to crop fields. This service has generally been free and therefore has received little attention in agricultural management. If wild pollinators are lacking or additional pollination is required, as is the case in many intensive agricultural production systems, farmers in some developed countries can buy or rent managed honeybees or sometimes other species (e.g. bumblebees, alfalfa leafcutter bees and alkali bees). Both options - i.e. use of wild species and managed bees - have recently come under pressure, a development that is sometimes referred to as the 'pollination crisis'. Of the interactions and overlaps between these key groups, that between soil invertebrates and BCAs is the most important, and further research is needed to evaluate the scope and impact of manipulation of the soil ecosystem to conserve or encourage beneficial BCAs. 
Keywords: Soil, Biological control, Pollination, Arthropoda, Insecta, Annelida, Nematoda, Ecology, Plant pests, Interactions

\section{Introduction}

Invertebrate species are predominant in the foodwebs, and among the ecosystem engineers, associated with agriculture. They have a major influence on productivity and therefore play a key role in food security. The vast majority of the invertebrate species in agro-ecosystems belong to the phyla Arthropoda (especially the Insecta), Annelida (segmented worms) and Nematoda. From an ecological perspective, these animals play important roles in foodwebs as primary consumers (herbivores); higherorder consumers (predators, parasitoids and hyperparasitoids); mutualists (facultative and obligate pollinators); parasites of plants, invertebrates and vertebrates; and saprophytes (mediators of decomposition, and energy and nutrient flows into and out of agricultural ecosystems). Soil invertebrates include ecosystem engineers that are powerful drivers of soil physical functions (water dynamics, aeration and protection from erosion hazards). They play an important role in carbon cycling, as they control the carbon sequestration process and influence greenhouse gas emissions. The different roles that invertebrate species play above- and below-ground in an agricultural ecosystem are responsible for a complex web of direct and indirect interactions, which in soils manifests as selforganized systems of different sizes and functions. Subtle changes in the interactions between species at different trophic levels within food webs can dramatically modify the impacts of arthropods on plant productivity in agricultural systems.

All human societies depend on a healthy and productive natural environment. If the capacity of ecosystems to produce goods and services is diminished, it is normally the poor who are most seriously affected. They often depend directly on forests, fisheries and agriculture, and tend to be most vulnerable to environmental problems, such as floods or crop failures, that result from ecosystem or land degradation. Given that terrestrial ecosystems provide roughly $99 \%$ of the world's food supply, and that the world's population is close to 7 billion $\left(10^{9}\right)$ and increasing at a rate of $1 \%$ per year, viable agricultural systems are critical to food security and poverty alleviation. The question is whether it will be possible to develop a sustainable agriculture that is able to feed these numbers and meet increasing consumption patterns in an ecologically compatible way? This question is even more critical given that other human needs - biofuels, urbanization, not to mention biodiversity conservation and climate regulation - also place increasing demands on land use. Assessing the sustainability of agriculture, and thereby predicting the future state of food security, requires prior understanding of the functioning of agricultural systems and the intricate relationships that exist between belowand above-ground biodiversity.

Losses of biodiversity have been escalating with the growing encroachment of human activities on ecosystems and increasing intensification of land use to meet demographic and socio-economic pressures. The multitude of small organisms associated with production systems, from pollinators to beneficial predators and soil organisms, has been overlooked. Reduction in the use of biodiversity in agriculture is driven by the increasing pressures and demands of urban and rural populations, by the global development paradigm, and by market forces that are favouring specialization and intensification but do not, as yet, internalize the cost of land degradation.

For this review, we focus on three key groups that act in a positive way on agriculture, and may be used, manipulated or moved to benefit agriculture: soil invertebrates, biological control agents (BCAs) and pollinators. We do not include herbivores, which in agricultural ecosystems are usually pests of the crops being grown, or feeding on the weeds growing among or adjacent to the crops. Although these organisms play an important role in breaking down living plant material to start the nutrient recycling process, their net impact on agriculture is mostly negative, and there is no obvious scope to manipulate them except through pest management for the benefit of agriculture. Similarly, we do not cover the relatively small but important contributions that invertebrates make as the sources of agricultural products (silk, honey, dyes, etc.) or as food items; these aspects are important, and the use of invertebrates as food for humans or domesticated animals is likely to increase in future, but as yet their use is limited on a global scale. We focus on whole organisms (as opposed to genetic material or genetic information), which play key roles in agricultural systems and have the potential to be manipulated to the benefit of agriculture. We restrict the scope of this review to terrestrial agriculture, and exclude marine and aquatic production systems. All terrestrial agricultural systems are considered, including forestry and pasture, but the main focus is on crop production systems. In addition to their role in crop production, BCAs play a role in the protection of stored crops, but this role is not treated as a separate topic. In section 'Overlap and interactions between the key groups', we briefly introduce the overlaps and interactions between the three key groups. The most important research gaps that struck us in preparing this review are summarized in the concluding section. 


\section{Soil Invertebrates}

Soil invertebrates are a very important component of agricultural biodiversity, and largely determine the structure and the basic functions of natural ecosystems. Key taxonomic groups of soil invertebrates include Nematoda, Oribatida, Collembola, Diptera, Hymenoptera, Isoptera, Myriapoda, Isopoda, Arachnida, Coleoptera, Mollusca and Oligochaeta. They are an integral part of agricultural ecosystems and are key actors in maintaining soil health, ecosystem functions and production. We treat this group first in this review and in more detail because of its key role at the root of the bottom-up processes governing agricultural productivity. The presence of a range of species and organisms capable of supporting critical soil processes is essential for the maintenance of healthy productive soils in the face of changing environmental conditions. The decline of these soil communities and the fact that their beneficial functions in agricultural ecosystems have been overlooked have certainly contributed to increased rates of land degradation, nutrient depletion, fertility decline, water scarcity, loss of crop productivity and yield reductions, although this has yet to be quantified. The loss of species with unique roles can have very drastic ecological effects that lead to long-term deterioration of soil fertility and agricultural productive capacity.

Conversely, the deliberate or accidental introduction of a keystone species may have detrimental or beneficial effects, depending on the context. A keystone species is one whose presence and role within an ecosystem has a disproportionate effect on other organisms within the system - a species that plays a fundamental role in maintaining the plants and animals in an ecosystem. An alien species introduced into an agricultural system may have detrimental effects through the elimination of important indigenous species so that ecosystem services are disrupted or positive effects by the elimination of reduction of species whose effect would otherwise be to reduce crop yield. Relatively, few studies have addressed the concept of soil invertebrates as keystone species, but there can be positive and negative impacts. Studies in Amazonian pastures by Chauvel et al. [1] showed that the disappearance of native soil macrofauna when forest is replaced by pasture after slash-andburn leads to the invasion of a pantropical earthworm species, Pontoscolex corethrurus (Müller) (Glossoscolecidae), that rapidly increases its population and transforms the soil structure, leading to degradation of pasture and reducing grass productivity. Conversely, experimental removal of one large native earthworm keystone species (Martiodrilus carimaguensis Jiménez and Moreno; Glossoscolecidae) in the Colombian Llanos led to soil degradation and problems such as greater soil compaction, weed invasion, reduced soil carbon and reduced plant biomass compared with areas where the species was not excluded [2].
Soil invertebrates interact with one another and with various plants and other animals in the ecosystem, forming a hierarchy of self-organized systems which span at least three scales of organization: microfoodwebs that operate in aggregates (ca. 50-100 $\mu \mathrm{m}$ in size) and interaggregate spaces; functional domains of ecosystem engineers which extend over scales of centimetres to metres; and mosaics of functional domains which cover several square metres [3]. We still do not know how many soil invertebrate species exist worldwide, and there is almost no soil where we are able to identify or even quantify all the resident invertebrate species ([4], but see [5]). Soil fauna is relatively poorly represented in the scientific literature and relevant web sites compared with aboveground communities. The less-charismatic soil organisms receive less scientific attention than the more visible and accessible above-ground animals. An overview of the number of described species versus the estimated number of species that remain undiscovered for the major taxa of soil animals (modified from [6]) indicates that the smaller the taxa are, the more they are disregarded in biodiversity surveys. Correspondingly, the taxonomic deficit (the ratio between the estimated diversity and the number of described species) tends to be higher for small-body-sized invertebrates [7]. Gaps in taxonomic knowledge make it difficult to generalize about the diversity of soil organisms. Even in the most intensively studied groups such as Lumbricidae (earthworms), the use of molecular identification tools (DNA barcoding) has revealed an unsuspected number of cryptic species that cannot be distinguished on a morphological basis [8].

Environmental factors shape the structure of communities across spatial scales, from patches to landscapes and biosphere. A series of abiotic and biotic filters sift species out of a regional pool [9]. Following this idea, the 'species pool hypothesis' considers local species diversity as part of a larger species pool at the regional level, i.e., the number of species potentially present in a given region [10]. The impact of anthropogenic activities on community diversity may thus be considered a result of modifications to the natural filters or the creation of new filters. This process occurs at various scales, ranging from the local (changes in biotic interactions to modification of the vegetation or introduction of exotics) to the ecosystem (ecosystem alteration or conversion to agro-ecosystems) and the landscape (habitat fragmentation or global change).

\section{Classification of soil invertebrates}

Soil biodiversity has generally been classified by size [11] or by the functions and processes that the organisms mediate [12]. Three main groups are distinguished according to body size [11]: macro-invertebrates or macrofauna (body length $>2 \mathrm{~mm}$ ), meso-invertebrates or mesofauna (body length ranging between 0.2 and $2 \mathrm{~mm}$ ) and micro-invertebrates or microfauna (body length $<0.2$ 
$\mathrm{mm})$. Soil invertebrates include 'full-time inhabitants' - such as many micro- and meso-arthropods, earthworms and macro-invertebrates - and 'part-time inhabitants' such as soil-dwelling insect larvae and adults, such as solitary bees in semi-arid areas or mound-building insects [13].

\section{Functional classification of soil invertebrates}

As Wolters and Schaefer [14] state, soil invertebrates contribute significantly to many ecosystem functions including decomposition, nutrient cycling and maintenance of soil physico-chemical properties. They define a functional group as 'a set of species that have similar effects on a specific ecosystem-level biogeochemical process'. No single classification exists, as the criteria used in classifying organisms and the degree of subdivision applied are functions of the question being addressed (see [15]). The functions that soil biota carry out depend largely on the efficiency of their digestive systems (which themselves depend on the organisms' interactions with soil microorganisms, such as bacteria) and on the occurrence and abundance of the biogenic structures they produce in the soil. A biogenic structure is a physical structure of biological origin, e.g. termite mounds, earthworm casts, etc. Using these two criteria, three large functional groups of invertebrates can be distinguished [16]:

1. Micropredators - within this group are the smallest invertebrates, including nematodes. They do not produce biogenic structures. Their main role in soil is to stimulate the mineralization of soil organic matter by preying upon micro-organisms inside soil micro-foodwebs [17], but they also feed on larger organisms. Micro-foodwebs play an important role in ecosystems where soil ecosystem engineers have been eliminated, as in intensive high-input agricultural systems and some deserts.

2. Litter transformers - some members of the mesofauna and macrofauna live in the leaf-litter layer and participate in the decomposition of plant litter [16] through comminution (breaking up particles) and digestion. They rely on micro-organisms for their digestion, mainly using the external rumen strategy: their faecal pellets act as incubators and they re-ingest them after some period of incubation to take advantage of the assimilable organic compounds released and probably also the microbial biomass accumulated [11]. They produce structures in the litter soil environment, which, being mostly organic, are usually fragile and short lasting. Some litter transformers, as they change resources from one physical state to another, also carry out some soil ecosystem engineering activity; for example, Diplopoda (millipedes) ingest leaf litter and produce faecal pellets with structure and physical properties that are different from the previously ingested plant litter.

3. Ecosystem engineers (sensu [18]) - This functional group comprises organisms that produce solid organo-mineral physical structures through which they are able to modify the availability or accessibility of water, trophic and spatial resources for other organisms. They include earthworms, ants and termites and a few other animals that can excavate soil and produce a wide variety of aggregated structures that have physical and chemical properties different from the surrounding soil. Their activities and production of biogenic structures can modify the abundance of organisms and the structure of their communities. The accumulation of the structures produced by ecosystem engineers forms functional domains in soil: the 'drilosphere' of earthworms, 'termitosphere' of termites or 'myrmecosphere' of ants. These provide habitats for rather specific communities of smaller invertebrates and micro-organisms (Figure 1). Soil ecosystem engineers also play important roles in the basic soil processes: hydric functions (water infiltration, storage at different tensions and release), organic-matter dynamics (sequestration in stable aggregates), soil chemical fertility and plant growth [16, 19]. Dung beetles, soil-nesting bees, solitary predatory wasps, invertebrate root herbivores and desert isopods, among other invertebrates, also dig small holes and burrows in the soil. However, the effects of these invertebrates in soil ecosystems are more localized and, with some exceptions, their roles have barely been assessed.

\section{The role of soil invertebrates in key functions relevant for agriculture}

The presence of a range of species and organisms capable of supporting critical soil processes is essential for sustaining healthy productive soils in the face of changing environmental conditions. Ecosystem services, such as decomposition, organic-matter dynamics, nutrient cycling, carbon storage, energy flow, water infiltration and storage in soil and (to some extent) plant growth, are mediated by soil biota, which therefore contribute to the maintenance of ecosystem integrity $[16,20]$. Decomposition, a key function in soil, is a biological 'cascade' process during which resources are progressively transformed into different components. The resources in question may originate above or below ground, and include plant roots, plant litter, animal faeces, live and dead micro-organisms, invertebrates and other materials - down to the amorphous soil organic matter composed of fractions of different ages and chemical composition. Decomposition is determined by interactions among three components: soil organisms, physical environment (particularly climate and mineralogy of the parent material) and the quality of the decomposing resources [11]. The three components are not of equal importance, and they act at different scales of space and time. Lavelle et al. [21] proposed a set of 


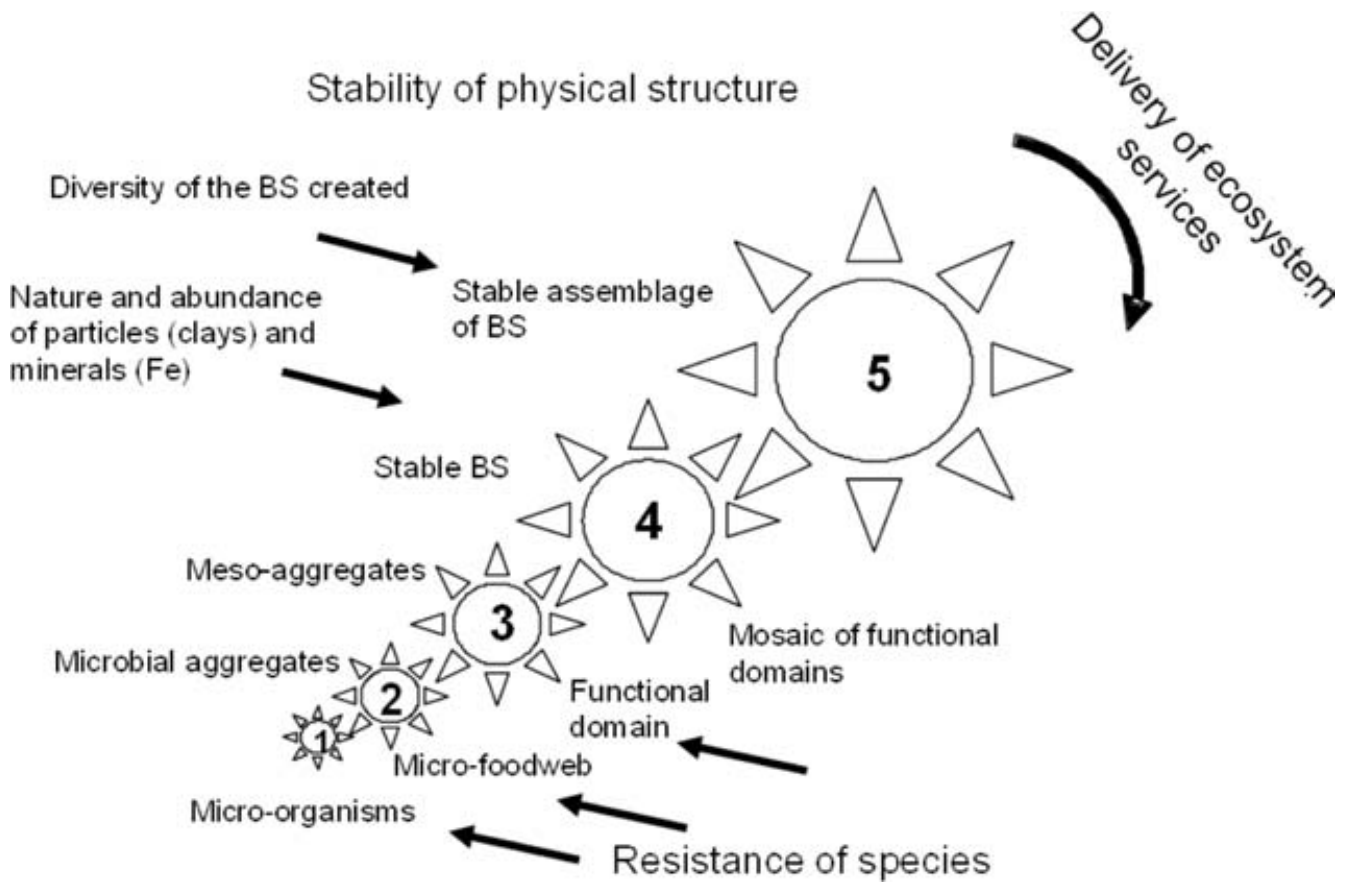

Figure 1 Self-organizing systems in soils at different scales. Scales are indicated by the numbers 1-5: from microbial films (1) - where most microbial transformations occur - to the landscape (5) where ecosystems services are delivered. The stability of the delivery of ecosystem services at scales larger than 5 is supported by the resistance of species to disturbances and/or the stability of physical structures, and other effects of invertebrates, that may extend their effects when they are temporarily absent. BS=biogenic structures. Source: Modified from Lavelle et al. [3]

hierarchically organized factors that determine microbial decomposition activities in terrestrial ecosystems at decreasing scales of time and space: climate >clay mineralogy+nutrient status of soil>quality of decomposing resources $>$ effect of macro-organisms (i.e. roots and soil invertebrates). Across this hierarchy, factors acting at higher scales of time and space tend to be dominant over those acting at smaller scales [22].

Many of the functions performed by soil animals contribute to the provision of important ecosystem services (Figure 2) at scales that are orders of magnitude larger than those of the organisms and their functional domains [12]. The loss of beneficial functional groups of soil invertebrates may result in the loss of key ecosystem processes, such as decomposition, nutrient cycling and soil structure, with important consequences in terms of land degradation, declines in crop productivity and greater food insecurity. There may also be wider consequences, such as increased poverty and the expansion of cultivated land for agricultural production. The maintenance of soil biological function is a key factor underpinning sustainable land-management practices.

Invertebrates create structures called functional domains in soil as they interact with other organisms (micro-organisms and plants) at discrete spatial scales. These structures are characterized by the composition of the associated communities (invertebrates and microorganisms), the physical structures created (aggregates and pores) and their corresponding species assemblages.

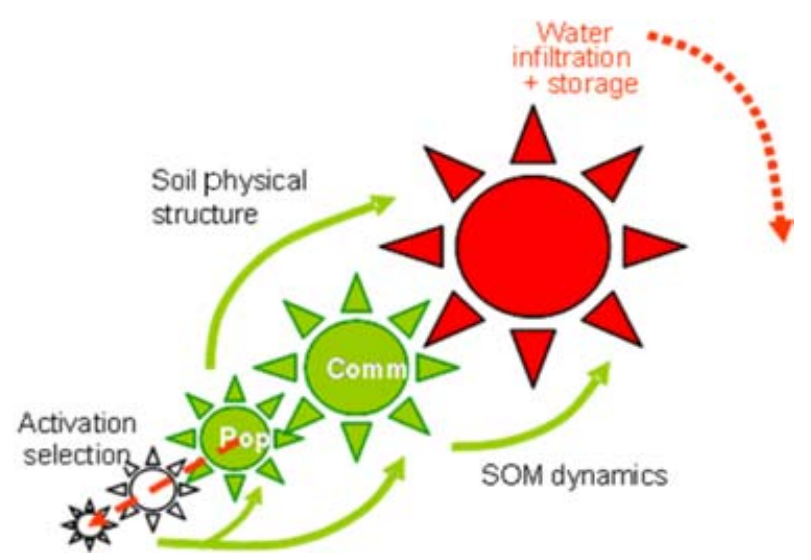

Figure 2 Effects of soil ecosystem engineers on the provision of ecosystem services at different spatial scales (cf. Figure 1). Individual populations (Pop) interact with microbial communities (red dotted line to level 1) which allow them to digest soil organic matter (SOM) and litter, thus activating SOM dynamics (lower green arrows). Populations also accumulate biogenic structures that influence soil physical structure (upper green arrow). Accumulation of these activities at the community level (Comm), results in the provision of ecosystem services at the landscape level (red level 5): water infiltration and storage and climate regulation via carbon cycling. Modified from Lavelle et al. [12]

Agricultural intensification normally has detrimental effects on biodiversity. It leads to an accelerating loss of biological diversity, both above- and below-ground. 
There are many reasons for this loss, including increasing homogenization of agricultural systems, monocultures, use of agrochemicals and excessive soil disturbance caused by continuous tillage. Soil biological communities are very responsive to land-use practices that directly modify the availability of trophic resources for soil organisms and hence affect the functions performed in the soil $[23,24]$. The number of species in a given community is usually lower after replacement of the original ecosystem. Exotic species tend to colonize these new habitats and eliminate endemic species that are poorly adapted to such disturbances. On the other hand, in many tropical American pastures that have been established in place of primary rainforest, earthworm communities are dominated by an indigenous species, $P$. corethrurus $[25,26]$. In some areas, however, the opposite has been reported and pastures derived from natural savannahs, alone or associated with legumes, are more likely to conserve the native earthworm community than those established on original rainforest sites, although there can be specific responses to the perturbation, such as increases in biomass for some species [24, 27]. Sustainable management practices can reduce the negative impacts on soil invertebrates with beneficial functions and maximize the positive (synergistic) effects in agricultural lands. Management options should address plot and landscape scales. At the plot scale, maintenance of permanent plant cover, management of organic inputs and minimum tillage have proved to be efficient means of maintaining active invertebrate communities of all the different functional groups [28, 29]. At the landscape scale, mixing agroecosystems and natural ecosystems facilitates the recolonization of cropped soils through the movement of invertebrates from 'source' plots to 'sink' plots [24].

Physical engineering: the role of biogenic structures Soil aggregation is a process whereby soil organisms perform essential soil ecosystem services, such as carbon sequestration and water infiltration. Aggregation is the binding of soil particles in solid assemblages of different sizes (micro $<50 \mu \mathrm{m}$, meso $50-1000 \mu \mathrm{m}$ and macro $>1000 \mu \mathrm{m})$. It results from the accumulation, over long periods of time, of biogenic structures (earthworm casts and burrows, termite faecal pellets and constructs, ant galleries and macrostructures) produced by aggregateforming invertebrates and roots, their interactions with microbial communities, and physical interactions among soil particles. In fact, most of the macro-aggregate structure of soils is of biogenic origin and has been formed by the activities of soil invertebrates and roots, sometimes over many years. The organisms operate at small spatial and temporal scales, but biologically formed aggregates may persist for several years or more, depending on conditions [30]. The remarkable microstructure of some soils (oxisols) of the Brazilian Cerrado (savannah) that confers a very porous structure in spite of a mostly clayey texture is said to be the result of several centuries of accumulation of termite pellets, $50-100 \mu \mathrm{m}$ in size [31]. The Colombian Llanos (plains) have soil with similar textures, but the lack of such termite activities has resulted in very compact soils with average bulk densities of $1.6-1.8 \mathrm{~g} / \mathrm{cm}^{3}$ [32] compared with 0.8 in the Brazilian Cerrados. Practices that eliminate soil ecosystem engineers may not immediately impair soil conditions and the resulting ecosystem services, as biogenic structures do not immediately cease performing their functions. This characteristic gives soils their capability to resist disturbances. It also masks, for a time, the negative effect of practices that impair soil invertebrate communities because the beneficial effects produced by these communities may last several years or decades after they have been eliminated.

\section{Chemical engineering: the formation of natural compost and nutrient release}

Litter transformers are the main actors in the process that - via comminution and chemical transformation (mainly operated by associated micro-organisms) - progressively transforms freshly dead organic matter into humus while nutrients are progressively released. This process involves a wide range of invertebrates, ranging from the tiniest detritivorous nematodes or protists through the highly diverse and abundant microarthropods and enchytraeid worms to the largest litter transformers found in litter systems (Isopoda, millipedes, centipedes, epigeic (=litter-dwelling) earthworms) and their respective predators.

Nutrient release is the other important chemical engineering function controlled by invertebrate activities. One pathway through which this occurs is the welldocumented process whereby nutrients accumulated by bacteria and fungi in their biomass are further released as nitrogen and phosphorus excretion, in mineral forms, by their micropredators [33-36].

Plants (producers) provide both the organic carbon required for the functioning of the decomposer subsystem and the resources for obligate root-associated organisms such as root herbivores, pathogens and symbiotic mutualists [37, 38]. Direct trophic pathways, such as root herbivory, are another important process by which nutrient release is affected. Root-associated organisms and their consumers influence plants more directly, and they also influence the quality, direction, and flow of energy and nutrients between plants and decomposers [37-39]. These close interactions between plants and root herbivores may be direct drivers of plant community diversity, although more studies are needed on consequences of the biodiversity of these soil organisms [37]. Another pathway is release in fresh faecal pellets by earthworms and termites. Earthworm casts contain quite high concentrations of mineral nitrogen (as ammonium, $\mathrm{NH}_{4}{ }^{+}$) and assimilable phosphorus, a product of the metabolism of the animals and enhanced microbial activities in their guts ([40,41] and references therein). 
Biological engineering: foodweb effects and plant health

Soil ecosystem engineers have very close relationships with microbial communities, which they selectively stimulate at different scales according to rules that are still poorly understood. Foodweb controls are known to play a role in the release of mineral nutrients from bacteria and fungal grazing by micropredators [3, 42]. These effects are generally embedded in a more general control operated by an ecosystem engineer in its functional domain (e.g. the rhizosphere of roots or drilosphere of earthworms) [34]. The most efficient organisms in this process are nematodes and protists, which maintain high densities in many soils and are the most resistant part of soil faunal communities.

Biological engineering also produces robust benefits for plant growth and plant protection. These effects have been fairly well documented for earthworms. Plants generally grow much better in the presence of earthworms than in their absence (see section 'BCAs and pollinators').

\section{Management of soil invertebrate activities}

\section{Direct management practices}

These practices involve intervening in the production system in an attempt to alter the abundance or activity of specific groups of organisms [28]. Examples of direct interventions include: (i) inoculation of seeds or roots with rhizobia, mycorrhizae, fungi and rhizobacteria to enhance soil fertility; and (ii) inoculation of soil or the environment with BCAs (for pests or diseases), antagonists or beneficial fauna (e.g. earthworms).

For example, in southern India, the long-term exploitation of soil under tea gardens has led to impoverishment of soil fertility and stabilization of yields despite increasing use of external inputs such as fertilizers and pesticides. Fertilization Bio-Organique (FBO) technology, i.e. the application of high-quality organic matter and earthworms, has been very effective in increasing tea yields which have increased by $79.5-276 \%$ (more than achieved by the application of fertilizers alone) - owing to their favourable effects on physical and biological soil properties [43]. More research is needed on the production and application of beneficial soil invertebrates in this way.

\section{Indirect management practices}

Indirect interventions mean the management of soil biotic processes through manipulation of factors that control biotic activity such as habitat structure, microclimate, nutrients and energy resources, rather than the soil invertebrates themselves [28]. Examples include the application of organic materials to soil, reduced tillage, fertilization, irrigation, green manuring and liming, as well as cropping-system design and management.

Examples from Carimagua (Colombia) suggest that the arrangement of experimental plots allocated to different crops may favour the conservation of locally high densities of earthworms and soil biodiversity. Placing pastures alongside cropped plots can accelerate the recovery of earthworm populations in the cropped plots. These spots may serve as reservoirs and refuges for the colonization of depopulated areas [44]. Through such practices, earthworms can be harnessed to improve ecosystem health [29]. Other agricultural practices in tropical countries in Africa (Case study 1), Asia and South America take advantage of the beneficial functions provided by soil invertebrates in a variety of ways.

\section{Conclusion}

Soil invertebrates are a key component of agricultural landscapes. They participate in essential soil processes for the maintenance of healthy, productive, soils in the face of changing environmental conditions. In general, agricultural practices have a negative impact on soil invertebrate communities, causing the disappearance of some species. Such effects disrupt the provision of beneficial soil functions and ecosystem services.

The importance of interaction between soil invertebrates and soil micro-organisms is worth reiterating. The activities of soil invertebrates stimulate microbial activity in soils, and micro-organisms are in intimate relationships with soil invertebrates, helping them degrade highly complex compounds such as cellulose.

\section{BCAs}

Biological control is defined here as the use of natural enemies to regulate pest populations. Natural enemies of pests are thus BCAs and provide an ecosystem service $[45,46]$. Integrated pest management (IPM) is 'a strategy of pest containment which seeks to maximise natural control forces such as predators and parasites [i.e. parasitoids] and to utilise other tactics only as needed and with a minimum of environmental disturbance' (Glass [47]). Thus, biological control, particularly natural biological control, underlies all IPM programmes.

BCAs are generally present in and around agricultural ecosystems, where they feed on pests and regulate their numbers. Where BCAs are absent, or are not present in sufficient numbers to regulate pest populations, they may be introduced into the cropping system. Pests are generally considered to include all species (invertebrate, vertebrate, weeds and diseases) causing harm to human interests (food, fibre, other agricultural products, environment and health). In this review, we refer to invertebrate pests (or subgroups such as arthropod pests or insect pests), vertebrate pests, weeds and diseases. We explicitly exclude diseases and parasites of humans and their invertebrate vectors, as well as diseases of livestock. However, we do include ectoparasites of livestock and 
pests arising from agricultural practices (e.g. nuisance flies).

Implicit reliance on 'natural biological control' is a feature of almost all production systems. For example, the majority of the species that infect, feed on or compete with any given crop do not cause sufficient damage to warrant treating them as pests, and thus it can be assumed that they are regulated by a combination of BCAs, crop resistance (and tolerance) and abiotic factors. The value of this regulatory service has been estimated worldwide at US $\$ 400$ billion $\left(10^{9}\right)$ annually, US $\$ 25 /$ ha/year in the world's grasslands and US $\$ 24 /$ ha/year for croplands (US dollars, 1994) [45], although these figures have been criticized on methodological grounds. Losey and Vaughan [48] estimate that the biological control regulatory service has a value of US $\$ 450$ million annually in the USA alone, approximately US $\$ 11 /$ ha/year. For world croplands, the value of natural biological control ecosystem services is almost half the value of food production.

Natural biological control encompasses both unconsidered and implicit reliance on this ecosystem service, and manipulation of the service through conservation of biological control methods. In the latter form of natural biological control, habitat and practices within and around agricultural land are manipulated to expressly favour the presence of desired natural enemy species ([49]; Case study 2). Overall, natural biological control and conservation biological control are highly dependent on landscape-level processes and can be negatively affected by disturbance, landscape fragmentation and loss of biodiversity [50].

Classical biological control is the introduction of an exotic BCA of an exotic pest or weed into a new ecoregion (or a new country in the same ecoregion) with the purpose of regulating the pest's numbers (Case study 3). This strategy is a long-term approach to the regulation of invasive pests. Also known as introduction or importation of biological control, it requires the selection, introduction and establishment of one, or a very small number of $\mathrm{BCA}(\mathrm{s})$ that is/are likely to regulate the pest, while not causing any adverse impacts on other species in the new habitat. Classical BCAs, once established, become part of the natural biological control ecosystem service. Van Lenteren [51] estimates that classical biological control is applied on 350 million hectares worldwide.

Augmentative biological control differs considerably from the preceding two strategies. The BCA is introduced, usually directly onto the crop to be protected, once or several times in a cropping cycle (Case study 4). The purpose is to induce sufficient mortality in the target pest population to ensure that economic injury thresholds (levels at which damage costs more than the cost of control) are not exceeded during the current cropping season. The BCAs are generally purchased from suppliers, or produced by a growers' cooperative, and are mass reared on natural or factitious hosts or prey.
Van Lenteren [51] estimates that augmentative BCAs are applied on 16 million hectares annually.

As classical biological control and augmentative biological control using exotic BCAs involve the deliberate introduction of alien species, these processes are carefully regulated according to national legislation, which varies from country to country (e.g. [52]), and international standards, such as the 'International Standards for Phytosanitary Measures No. 3. Guidelines for the Export, Shipment, Import and Release of Biological Control Agents and Other Beneficial Organisms (ISPM3)' [53]. Furthermore, because BCAs are genetic resources, their international use is covered by the 'Nagoya Protocol on Access to Genetic Resources and the Fair and Equitable Sharing of Benefits Arising from their Utilization to the Convention on Biological Diversity' [54], in anticipation of which, Cock et al. [55] have argued that the biological control approach should be treated as non-commercial research, and that since the benefits are in the form of common goods, the benefit sharing with the source country might be best based on joint scientific research.

\section{Types of BCAs}

BCAs are all those species that are natural enemies of pests. They include invertebrates, vertebrates and microorganisms, although only invertebrates are considered in this review. BCAs are primarily predators, parasitoids and diseases of arthropod pests, and herbivores that feed on weed pests. Taxonomic study and genetic characterization is still needed for most groups of BCAs; for example, recent studies have revealed that what appear to be generalist BCA parasitoid species are often a complex of previously unrecognized specialist species [56-58].

Almost all classes and orders of Arthropoda contain species with predatory lifestyles, and arthropods dominate this guild in and around sustainable cropping systems. Predators consume more than one prey item, and generally many prey items, to complete development of the immature stages; and they often must feed as adults in order to reproduce. The Acari, Arachnida, Opiliones mites, spiders and harvestmen, respectively - are common predators, and among insects, the orders Odonata (dragonflies), Hemiptera (true bugs), Neuroptera (including lacewings), Coleoptera (beetles), Diptera (flies) and Hymenoptera (bees, ants and wasps) contain predator species of key importance in sustainable cropping systems. Although there are exceptions, most predators are generalist or oligophagous feeders - i.e. they consume more than one prey species, and often feed at more than one trophic level: eating herbivores, other predators, and, in the case of true omnivores, plants.

Parasitoid lifestyles are considerably more specialized, and are common only in the insect orders Diptera and Hymenoptera. Parasitoid females lay one or more eggs in or on a single host individual. As a result, a parasitoid 
individual normally kills only one host individual during its development. As the host is killed during parasitoid development, these species cannot be considered parasites; although they must overcome host defences, and form intimate physiological and biochemical relationships with their hosts, in much the same way that parasites do. As a general rule, parasitoids specialize on a few host species, and the life history of most parasitoid species is tied closely to that of the host or hosts, although some species are fairly broad generalists.

Diseases that act as BCAs are not specifically addressed in this study, although many points relating to invertebrate BCAs also apply to diseases. Nematoda include some true parasites that do not kill their hosts. The entomopathogenic nematodes (EPNs), some of which are used in augmentative biological control, occupy a niche that is generally considered to be a disease functionally - mainly because reproduction in the dying host leads to a large number of individual nematodes being produced by a single dead host. Steinernema spp. (Steinernematidae) and Heterorhabditis spp. (Heterorhabditidae) are produced for use as augmentative biological control products. Infective nematodes are suspended in water and are applied as a spray or a drench, in much the same way as a microbial pesticide. Kabaluk et al. [59] list six commercially produced species in these two genera in OECD countries which are applied against a wide array of pests including Lepidoptera (caterpillars), Coleoptera, Diptera, Siphonaptera (fleas) and Orthoptera (e.g. mole crickets and mormon crickets).

Natural biological control is based on all the abovedescribed types of BCAs. The key species vary depending on the pest species and the location. In general, natural biological control relies on a community of generalist and specialist invertebrate predators and parasitoids, as well as diseases.

In contrast, classical biological control of arthropods uses only the specialized natural enemies that are deemed least likely to have undesirable non-target effects. This means an emphasis on specialized parasitoids (Hymenoptera and Diptera) and a few specialized predators, such as some Coccinellidae (ladybird beetles or ladybugs) and Diptera.

Augmentative biological control mostly uses a mixture of specialist parasitoids that target an individual pest, oli-

AQ2 gophagous predators and EPNs (usually indigenous) which will eat or attack several species of pest. Most new BCAs being developed for use in augmentative programmes are either specialized parasitoids or indigenous species. This strategy minimizes the risks that BCAs will have undesirable impacts on biodiversity. If an augmentative BCA is exotic to an ecoregion, its first release must be reviewed with as much rigour as is applied to classical BCAs, in accordance with national regulations or international standards such as ISPM3 [53].

Biological control of weeds with invertebrates is, at present, mostly tackled using classical biological control.
There is, however, some potential for augmentative releases of classical arthropod BCAs of weeds [60]. Any herbivore that is suitably host-specific and likely to be damaging can be used. Among invertebrates, these are almost all insects, with an increasing preponderance of beetles, particularly Curculionidae or weevils and Chrysomelidae or leaf beetles, being used as classical BCAs against weeds.

\section{Main targets of biological control}

The main targets of biological control used in agriculture have been invertebrate pests of crops (including forestry) and weeds of crops (including pasture). The invertebrate pests of stored products are also valid targets for biological control, but the acceptable thresholds for damage are usually lower than can, at present, be reliably achieved with biological control. Parasitoids are used against fly pests in high-intensity animal-production units such as feedlots and poultry barns. Dung beetles have been introduced in various parts of the world to aid in the decomposition of dung in pasture and rangeland, thus reducing the abundance of nuisance pests and disease vectors arising from the dung. Ectoparasites of domestic animals (e.g. mites, ticks, mosquitoes and tsetse flies) are also a potential target for biological control, but research is focused on the use of micro-organisms as BCAs in this niche. Environmental pests (i.e. pests of natural, amenity and built ecosystems) and pests of medical importance are also valid targets - with significant successes having been achieved against the former - but beyond the scope of this study.

Classical biological control is mostly used against exotic targets. Although indigenous pests have been targeted using exotic BCAs in the past, this practice has declined because of the increased risk of non-target effects. All exotic pests are potential targets for classical biological control, but in practice it is usually those that cause most damage, or prove intractable to other control measures, that are prioritized in much of the world. In some countries (e.g. Australia and New Zealand), all new pests (especially weeds) are considered first as potential targets for classical biological control. Classical biological control has worked in many different situations, but it is more likely to be effective in stable agro-ecosystems (e.g. forestry, plantations and pasture), where there are no indigenous species closely related to the target (less chance of non-target effects, so more choice of agents), and on islands (where the less-diverse indigenous natural enemies are likely to be less effective).

Augmentative biological control using invertebrates has been used almost exclusively against invertebrate pests. Until recently, the majority of the targets of augmentative biological control were exotic, cosmopolitan, pests of crops grown under cover. These pests are easily moved in trade of live plants and plant parts. 
In general, the pests that are successfully targeted with augmentative BCAs have a predictable seasonal occurrence, and a reasonably large potential market. This is because augmentative BCAs are produced for sale. Most augmentative BCAs cannot be stored, and production must be planned several weeks in advance to meet anticipated demand. There are roughly 13 targets of augmentative BCAs in covered crops (depending on how one lumps and splits target groups and species). In addition, egg parasitoids, Trichogramma spp. (Hymenoptera: Trichogrammatidae), have been used against the eggs of caterpillar pests of forest crops, and indigenous species of Trichogramma and other egg-parasitoid species are increasingly being used against important exotic Lepidoptera pests of food crops, such as the diamondback moth (Plutella xylostella (L.); Lepidoptera: Plutellidae) and European and Asian corn borers (Ostrinia nubilalis (Hübner) and Ostrinia furnacalis Guenée; Lepidoptera: Crambidae). The application of indigenous, augmentative BCAs against both exotic and indigenous targets has significant potential for growth.

\section{Scale of use of BCAs}

The application of biological control is widespread in forests, grasslands and rangelands, and in sustainable cropping systems. BCAs contribute to the regulation of pests that are present in these systems and to the regulation of populations that could potentially invade croplands. Even highly industrialized factory farms receive some benefit from the actions of natural BCAs in regulating populations of invading pests.

Use of natural biological control is facilitated through development of IPM programmes, and through field schools and workshops that encourage and educate farmers. In particular, farmers are encouraged to reduce the application of broad spectrum insecticides, as this encourages survival of BCAs on and around farms. As natural BCA communities are location-specific, development of natural biological control programmes is highly dependent on education and local knowledge.

At least 7000 introductions of BCAs involving almost 2700 BCA species have been made. The most widely used BCAs have been introduced into more than 50 countries. BCAs from 119 different countries have been introduced into 146 different countries (Table 1). High-income countries have made the most use of classical biological control, and have also been the main source of BCAs. Low-income countries have contributed slightly more BCAs than they have received. For a more detailed summary, see Cock et al. [55, 61].

Augmentative biological control against arthropod pests, using arthropod and nematode agents, takes place on $\sim 1.6 \times 10^{6}$ ha of land $[62,63]$. Egg parasitoids, mainly Trichogramma spp., are released against a number of pest Lepidoptera, five species of natural enemies are released
Table 1. The number of classical biological control introductions made in different countries up until 2006 (from [61])

\begin{tabular}{llll}
\hline $\begin{array}{l}\text { Number of } \\
\text { releases per } \\
\text { country }\end{array}$ & $\begin{array}{l}\text { Number of } \\
\text { countries }\end{array}$ & $\begin{array}{l}\text { Total number } \\
\text { of releases in } \\
\text { these countries }\end{array}$ & $\begin{array}{l}\text { \% of total } \\
\text { releases }\end{array}$ \\
\hline$>100$ & $12^{1}$ & 4231 & 61.6 \\
$50-100$ & $14^{2}$ & 997 & 14.5 \\
$10-49$ & 55 & 1399 & 20.4 \\
$1-9$ & 65 & 245 & 3.6 \\
& 146 & 6872 & \\
\hline
\end{tabular}

${ }^{1}$ In order: USA, Australia, Canada, New Zealand, South Africa, UK (almost entirely overseas territories), Fiji, Mauritius, India, France (mostly overseas territories), Israel, Guam.

2In order: Russian Federation, Italy, Barbados, Chile, Trinidad and Tobago, Ghana, Kenya, Philippines, Mexico, St Kitts and Nevis, Papua New Guinea, Greece, Peru, Bahamas.

against pests in orchards in Europe, and more than 30 agents are released against pests in greenhouse production systems worldwide [63]. Most of these programmes are directed against invasive exotic pests. Once established, and therefore endemic to a region, classical BCAs may be used as augmentative BCAs, as in the case of Cotesia flavipes (Cameron) (Hymenoptera: Braconidae) used in Latin America for augmentative biological control of sugar cane stem borer, Diatraea saccharalis (Fabricius) (Lepidoptera: Crambidae) (summarized in [62]). In the augmentative biological control sector, more than 170 species of natural enemies are produced and sold, but some 30 species make up more than $90 \%$ of the market worldwide. The trend in augmentative biological control is towards looking first for indigenous natural enemies when a new, even exotic, pest develops (Figure 3, Case study 5).

Costanza et al. [45] estimated the world's croplands at $1.4 \times 10^{9}$ ha. Given that augmentative biological control takes place on a very small fraction of this area, the potential market for augmentative programmes is enormous. Van Lenteren [64] estimated the area under biological control in greenhouses worldwide to be $\sim 32000$ ha, which is a very small fraction of the world greenhouse area: 2400000 ha (2 280000 in vegetables, 120000 in ornamentals). Given current trends in markets, and uptake of new agents by farmers, Pilkington et al. [65] predicted continuing increases in use of biological control in greenhouses.

\section{Advantages and disadvantages of biological control}

Biological control has some distinct advantages and disadvantages that set this method of pest containment apart from all others. BCAs exhibit no toxicity to humans or livestock. The vast majority of BCAs exhibit moderate to high specificity to targets. Unlike the long-lasting chemical insecticides, BCAs do not bioaccumulate (i.e. accumulate substances, such as pesticides, in organisms), and they do not contaminate ground and surface waters. BCAs are 
(a)

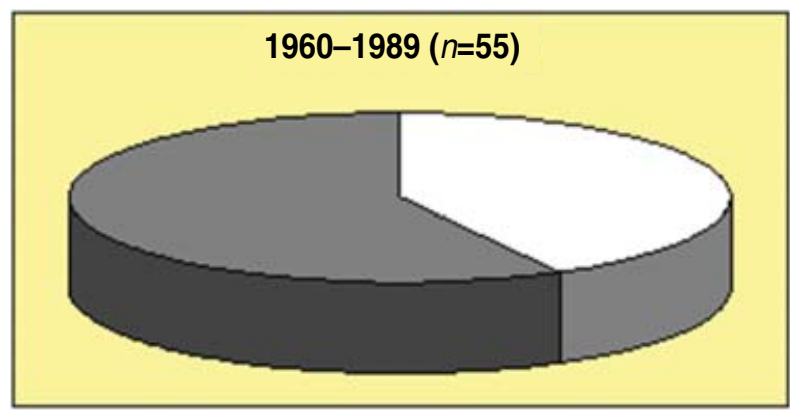

(b)

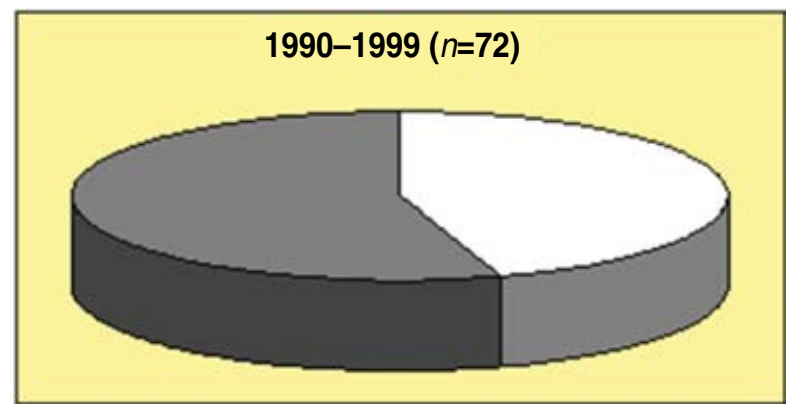

(c)

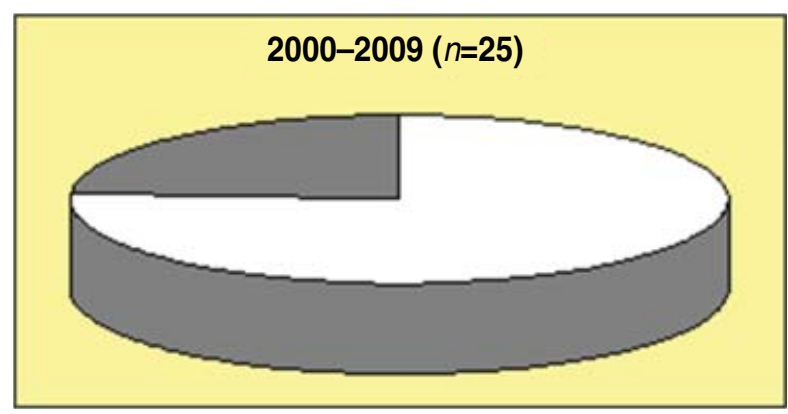

Figure 3 The changing proportions of first use of exotic (grey) and indigenous (white) natural enemies in augmentative biological control in Europe over time. Source: Cock et al. [61].

either naturally present (natural biological control) or, once introduced, establish and spread so that they attack the target pest throughout its range (classical biological control).

Natural biological control has a key benefit that it is naturally present in all agricultural situations and so is free to farmers. In many cases, it can provide adequate control of pests. In many others simple manipulations may allow natural biological control to keep pests at acceptably low levels. The use of broad-spectrum pesticides is incompatible with natural biological control. In many situations, natural biological control can provide substantial control of many pests and therefore should form the foundation of IPM. Further interventions should be selected and implemented so as to minimize the adverse effects on existing natural biological control. Classical and augmentative biological controls are two such examples.

Classical biological control is primarily used to control introduced pests, which may not be effectively controlled by indigenous BCAs. The introduction and establishment of a classical BCA leads to reproduction and spread of the introduced BCA so that it becomes part of the ongoing natural biological control. This process brings public good benefits to the country and its farmers, but does not generate income or profits for the implementing agency. The introduction of BCAs normally requires access to genetic resources (i.e. the BCAs) from another country and non-monetary mechanisms for sharing the benefits of what is basically non-commercial research [55, 61].

When neither natural nor classical biological control can solve a pest problem, augmentative biological control may be a good option. It is fully compatible with natural biological control, although conflicts may arise (e.g. with BCAs of weeds present in the same habitat). As, in most production systems, growers must purchase augmentative BCAs, these agents must be competitive with insecticides with respect to efficacy, predictability and cost. Augmentative biological control uses indigenous BCAs for preference, but - particularly when dealing with an introduced pest - BCAs may need to be introduced, and so access and benefit sharing will need to be addressed.

Integrating these different aspects of biological control in an IPM system can provide effective pest management that minimizes or obviates the need for pesticides: to the benefit of farm workers, the public who consume or use the agricultural products, and the environment. However, if growers are locked into an IPM system based on biological control and a new pest appears, there is a risk of significant losses and reversion to the use of pesticides if an effective BCA is not quickly available (Case study 6).

\section{Conclusion}

Losses to agricultural production due to pre-harvest and post-harvest pests can be very substantial. Different types of invertebrates provide biological control of pests. They form the basis of, and tools for, the IPM approach to crop pest management in many situations. A large fraction of the biological control ecosystem service relies on natural biological control. This is generally unmanaged, and vulnerable to disruption from disturbance, habitat fragmentation and loss of biodiversity. Classical and augmentative biological control are less widely used on a per-area basis, but have been more widely studied. All forms of biological control are critical components of IPM in sustainable production systems. Their potential is only partially tapped. Management and conservation of invertebrates that provide biological control of pests in crops is critical for food production and food security. 


\section{Pollinators}

A pollinator is a biotic agent (vector) that moves pollen from the male anthers of a flower to the female stigma of a flower to accomplish fertilization and seed setting [66]. Pollination services by animals, especially insects, are one of the most widespread and important processes that structure ecological communities in both natural and agricultural landscapes [67]. An estimated $60-90 \%$ of the world's flowering plants depend on insects for pollination [68] and these include a great many economically important plant species [69].

Crop pollination used to be (and often still is) provided by wild pollinators spilling over from natural and seminatural habitats close to crop fields. This service has generally been free and therefore has received little attention in agricultural management. If wild pollinators are lacking or additional pollination is required, as is the case in many intensive agricultural production systems, farmers can buy or rent managed honeybees (Apis mellifera L.; Hymenoptera: Apidae) or sometimes other species (e.g. bumblebees, alfalfa leafcutter bees and alkali bees). Both options for pollination service provision - i.e. use of wild species and managed bees - have recently come under pressure, a development that is sometimes referred to as the 'pollination crisis' (e.g. [68]).

Here, we provide a short review of current knowledge on, and estimates for the value of, crop pollination in global agriculture, the insect species providing the pollination services and the threats to the sustainability of these services.

\section{Crop pollination as an ecosystem service: importance and value}

Crop pollination is a key ecosystem service vital to the maintenance of agricultural productivity. Using primary data sources from 200 countries, Klein et al. [70] concluded that fruit, vegetable or seed production from 87 of the leading global food crops is dependent upon animal pollination, while 28 of these leading crops are self- or wind-pollinated (Case study 7). Global production volumes give a contrasting perspective, as $60 \%$ of global production comes from crops that do not depend on animal pollination (e.g. most cereals and root crops), $35 \%$ from crops that depend on pollinators (most fruits, stimulants such as coffee and cocoa, and many vegetables), and $5 \%$ are unevaluated. Note that these estimates do not take into account the contribution of pollination to the production of animal forage, ornamental plants and seeds, fibres, non-timber forest products or subsistence crops that are not marketed.

Not all insect-pollinated crops depend $100 \%$ on insect pollination, and many crops can partially self- or windpollinate (Figure 4). Taking into account the level of insect-pollinator dependence and the production area for

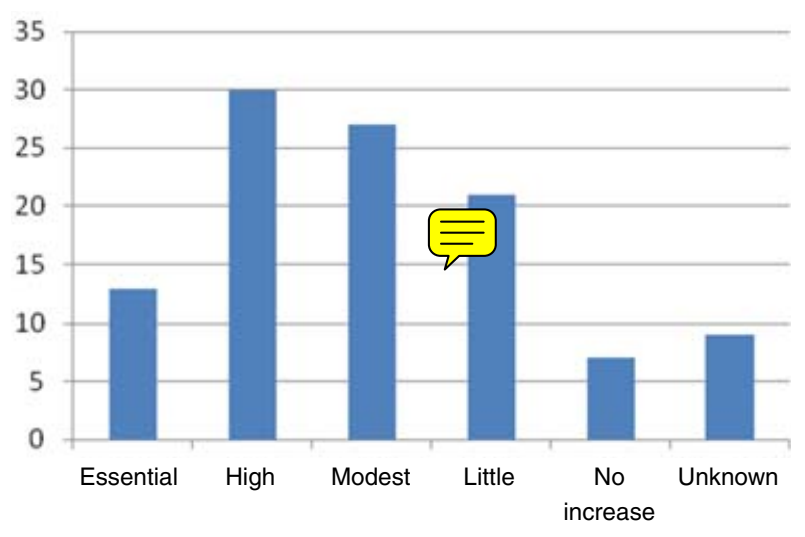

Figure 4 Level of dependence of crops on animalmediated pollination. Source: Klein et al. [70].

each crop, Aizen et al. [71] calculated the actual volume of crop production that directly results from the contribution of insects to pollination and concluded that $5 \%$ (developed countries) to $8 \%$ (developing countries) of food production would be lost if all pollinators disappeared. The percentage of pollinator-dependent agricultural crops has increased considerably over the last 40 years from 18.2 to $34.9 \%$ in developed countries and from 23.4 to $32.8 \%$ in the developing countries [71]. These findings suggest that the higher rate of increase in pollinator dependence in developing countries compared with developed countries might well continue into the future, which would warrant specific focus on those parts of the world.

Production volume does not necessarily represent value, because of the disproportionate nutritional or consumer value of specific crops. In fact, insect-dependent crops have on average a five times higher economic value than insect-independent crops [72]. For the subset of crops that is marketed, it is possible to calculate the actual market value of insect pollinators' contribution. Gallai et al. [72] estimated that the total value of insect pollination to global agriculture is $€ 153$ billion per year, which represented $9.5 \%$ of the value of the world agricultural production used for human food in 2005. This may not seem a high proportion, but the figure is much higher for specific groups of products (e.g. 39\% for stimulant crops including coffee and cocoa, $31 \%$ for nuts and $23 \%$ for fruits) and can thus be very high for countries with a strong economic dependence on such crops. Clearly, insect pollination is an important agricultural input.

The value of crop pollination can be estimated to be much higher (5-100 times) when calculated as the investment needed to fully replace the pollination services [73], for example by hand pollination or large-scale dusting of pollen in crop fields (e.g. manually or by helicopter). In some cases, the replacement value of the pollination services may be significantly higher than current market prices for commercial pollination. In many 
cases, loss of wild pollinators can potentially be replaced by introducing managed pollinators. This has been done for centuries using managed honeybees, but recent declines in managed honeybees may lead to much higher prices for hiring colonies or even a shortage of hives for crop pollination. Decreases in honeybee pollination services have already caused problems for some crops. For example, Californian almond growers now pay more than US $\$ 100$ per hive, up from US $\$ 40$ less than 7 or 8 years ago as a result of honeybee shortages and have even started to import honeybee colonies from Australia in order to save their US $\$ 250$ million crop $[48,74]$.

\section{Crop-pollinating insects}

Insects are the main crop pollinators among animals. Bees often contribute the most, but in some specific crops most pollination is performed by other groups (e.g. midges for cocoa pollination, moths for pawpaw (papaya) pollination, and weevils for oil palm - see Case study 8). Moreover, in many other crops some pollination is carried out by insects other than bees. Bees are generally good pollinators because of their obligate dependence on flowers (pollen is fed to their offspring), their hairy bodies to which pollen grains easily adhere, and their centralplace foraging strategies (i.e. the need to go back and forth to their nest). Flies, beetles, ants, butterflies and moths are among the other flower-visitor groups.

The contribution of most of these species is restricted to the members of their wild populations, because they are not managed. In such cases, the crop requiring pollination needs to be within the foraging range of the pollinator, which can be as little as tens of metres for small insects. This limits the use of wild pollinators in intensive monocultures of annual crops, with more chance of success in perennial crops, mixed cropping systems and more heterogeneous landscapes where there are adequate nesting and living conditions for the pollinators. When wild pollinators are not present in sufficient numbers, farmers can introduce managed pollinators to their fields.

Honeybees are the main managed pollinator and they are potential pollinators of most crops [70]. If a beekeeping industry is present, farmers can set up contracts with beekeepers to hire colonies for pollination purposes, with the beekeepers then maintaining their hives during the period of the contract. Over the last century, the growth in managed honeybee colonies (up 50\%) has not been able to track the $300 \%$ increase in demand for pollination of insect-dependent crops [75]. In addition, managed honeybee populations have recently come under severe pressure, with large local die-offs of $50-80 \%$ (see also section 'Threats to crop pollinator populations'). Together, this clearly creates uncertainty as to whether future demand for managed honeybees can be met by beekeepers' supply of colonies.
Even though a single species, such as the managed honeybee, can often do an excellent job as a service provider, pollination service tends to increase or be more stable where a larger diversity of potential pollinators is present in the system [76, 77]. There can even be indirect benefits to pollination as a result of species interactions, as in the case of sunflower pollination in the USA where the behaviour of native bees caused a change in honeybee behaviour, enhancing their pollination contribution [78].

\section{Threats to crop pollinator populations}

There is now evidence of a decline in individual species abundance and species richness among wild bees and other pollinators in Europe [79, 80] and North America $[81,82]$ probably as a result of multiple, interacting causes [83]. Pollinator losses seem biased towards species with particular traits, such as diet and habitat specialization $[80,84]$. Losing specific traits from pollinator communities might lead to loss of specific ecological functions, such as long-distance pollen dispersal if large-bodied bees disappear or pollination of deep flowers if long-tongued species are lost.

A multitude of drivers potentially affect pollinator abundance and diversity, and they are probably interacting in non-linear and unpredictable ways. Our knowledge on how individual drivers act is increasing, but interaction effects have rarely been studied, because of the practical difficulty involved in large-scale experimentation. An important set of drivers stems from land-use change, which results in agricultural intensification [77], loss of flower-rich meadows [79], increased pesticide use $[85,86]$ and habitat loss, degradation and fragmentation $[77,87]$. All have led to loss of pollinators' foraging and nesting habitats. These problems are further exacerbated by the arrival of invasive species, including new diseases and parasites [88] and, increasingly, by climate change $[89,90]$. As most natural landscapes around the world are human-dominated, it is likely that pollinator populations have changed, and possibly declined, in most parts of the world, although the responses of individual species to these drivers can range from increases in population, via indifference, to complete local extinction. This can be illustrated with the example of British bumblebees. As a group they have declined considerably (i.e. lower species richness) with several species now restricted to small local populations or virtually extinct. Other species, however, seem to persist in low numbers and 6-7 species occur in most urban gardens and seem to be thriving.

In addition to declines in wild pollinators, there is mounting evidence that managed honeybees are declining around the world. Domestic honeybee stocks declined by $59 \%$ between 1947 and 2005 in the USA [81, 91] and by about 25\% in central Europe between 1985 and 2005 [92]. In addition to socio-economic factors that are making beekeeping less attractive as a commercial venture or 
hobby, these declines are a result of the introduction of Varroa destructor Anderson and Trueman (Acari: Varroidae), an ectoparasitic mite of honeybees, from Asia (Case study 9). This mite has resulted in the disappearance of most wild and feral honeybee colonies in Europe and the USA, leaving only those kept by beekeepers [93-95]. However, in recent decades the beekeeping industry has diminished considerably in the USA and Europe - see figures above - despite having increased globally by about 45\% since 1961 [71].

The observed and expected declines in wild pollinators, combined with steep regional declines in managed honeybees (the only 'back-up' option), seem to suggest that the demand for crop pollination could outstrip the supply of wild and managed pollinators, particularly with respect to the ongoing increase in the proportion of pollinator-dependent agricultural crops (>300\% increase since the 1960s [75]).

\section{Conclusion}

Pollination services by animals, especially by insects, are an essential contribution to agriculture, on which many crops are dependent. Although crop pollination used to be (and often still is) provided by wild pollinators spilling over from natural and semi-natural habitats close to crop fields, if wild pollinators are lacking or additional pollination is required, as is the case in many intensive agricultural production systems, action is needed such as the provision of managed honeybees or sometimes other species. Both options - i.e. use of wild species and managed bees have recently come under pressure, and research is needed to avert a worsening 'pollination crisis'.

\section{Overlap and Interactions between the Key Groups}

In this section, brief consideration is given to ways in which the three key groups, soil invertebrates, BCAs and pollinators, may overlap or interact.

\section{Soil invertebrates and BCAs}

Many invertebrate pests and BCAs spend at least part, most or all of their life cycle in the soil, whether for pupation, as root feeders, as predators, for nest formation, or other purposes. Hence, soil ecology can be expected to have a significant impact on these groups of BCAs.

In particular, there are large and important groups of invertebrate predators that spend much of their time in or on the soil. Many species of ants nest below ground where they may act as ecosystem engineers [96], but are also important polyphagous predators both above- and below-ground [97]. Important beetle groups, notably
Carabidae [98] and Staphylinidae are associated with the top layer of soil, climbing plants to hunt, usually by night. Other groups of predators pass most or all of their lives in the soil, e.g. centipedes, entomopathogenic and predatory nematodes, and some groups of mites and spiders.

Evaluation of the impact of predators above ground is difficult, and usually requires an experimental approach [99]. Much less is known about the impact of BCAs below-ground, especially the smaller ones.

Specialist parasitoid natural enemies burrow in soil to look for hosts. Some scoliid wasps (Hymenoptera: Scoliidae), are known to parasitize the soil-dwelling rootfeeding white grub larvae of Scarabaeidae, which they locate by burrowing in soil [100]. For example, a complex of scarab larvae in Australian sugar cane crops are attacked by the scoliid, Radumeris tasmaniensis (Saussure), which can burrow to a depth of $1.2 \mathrm{~m}$, and a dexine tachinid, Rutilia sp. [101]. Cluster flies in the subfamily Polleniinae (Diptera, Calliphoridae) parasitize earthworms. The eggs are laid on soil, often near earthworm burrows. Once the larvae hatch, they burrow into the soil by following natural pore spaces, such as holes near plant stems or paths that earthworms have already created. By randomly moving through these pores, the larvae find their host worms [102]. In temperate regions, the adult flies overwinter in clusters in roofs, attics and other spaces of houses, where they can be a nuisance. Aleochara spp. (Coleoptera: Staphylinidae) are semi-specialist parasitoids of small flies including the anthomyiid cabbage root maggot, Delia radicum (Linnaeus), and burrow in soil in search of prey [103].

BCAs that live or spend time in the soil are subject to the attacks of various abiotic and biotic factors, especially pathogens and predators. Very little is known about the importance of mortality factors affecting BCAs below ground. This lack of knowledge means that suggestions of approaches to manage these mortalities in support of agriculture and food production are likely to be tentative and untested. Thus, if below-ground nesting ants are shown to be important predators of a key pest in a particular crop, then it can be suggested to use soil preparation methods that do not destroy ant nests, or that refuges be left within the farm where ants can nest undisturbed [104]. However, the implications of these measures on other aspects of soil ecology are not necessarily known, and the overall effect on crop economics cannot be predicted in detail.

There is increasing evidence and awareness of the importance of integrating above- and below-ground organisms to better understand complex multitrophic interactions [105-107]. For example, the negative impact of root herbivory by cabbage root maggot, $D$. radicum on plant quality slowed development of the caterpillar leaf feeder Pieris brassicae (Linnaeus) (Pieridae), which in turn reduced the size of its braconid parasitoid Cotesia glomerata (Linnaeus) and its ichneumonid hyperparasitoid Lysibia nana (Gravenhorst) [108]. Another plant-mediated 
example relates to the North American western corn rootworm, Diabrotica virgifera (Coleoptera, Chrysomelidae), an alien species in Europe, the larvae of which causes major damage to the root system of maize. Although western corn rootworm has been intensively studied for many years, it was only recently that studies in Europe showed that damaged roots of some maize varieties attract predatory nematodes, which attack the beetle larvae doing the damage [109].

Earthworms can have indirect effects on above-ground pests and their natural enemies. The presence of earthworms, Aporrectodea caliginosa (Savigny), interacting with drought conditions resulted in decreased numbers of aphids, Rhopalosiphum padi (Linnaeus) and parasitoids on barley in the UK [110]. Earthworms had similar effects on colonization of Tanacetum vulgare by aphids [111], and this would likely also have knock-on implications for populations of BCAs. Other interactions involving earthworms and below-ground pests are presented in Case study 10.

Generalist predators that may prey on above-ground prey are also favoured by practices that enhance soildwelling macroinvertebrate prey. Thus, certain soil conservation and organic farming practices enhance soil and surface structure to a degree that favours predators such as cursorial spiders [112].

\section{BCAs and pollinators}

There are important groups of natural enemies, particularly among Hymenoptera and Diptera, which rely on flowers for adult feeding and many in the process provide pollination services. The food sources could be crop flowers, but would be wild flowers or weeds when crops are not in flower. Syrphidae, Bombyliidae and Tachinidae are three families of Diptera recognized as both important pollinators and useful BCAs $[113,114]$. Of these, Syrphidae are the most important pollinator group among the Diptera, at least in temperate regions [115].

The parasitic Hymenoptera are not usually thought of as effective pollinators, but Scoliidae are among the more effective. Ichneumonidae and Chalcidoidea are also known to visit flowers, but are not important pollinators [115]. Solitary hunting wasps (Pompilidae, Sphecidae and some Vespidae) and gregarious wasps (some Vespidae) are predators of invertebrates and also visit flowers. Pompilidae and Sphecidae are not considered important pollinators, but Vespidae may have a significant role in some flower groups [115].

Ants (Formicidae) are both important predators and flower visitors. However, as they do not fly to visit flowers, they rarely cause cross-pollination, and their method of entry to the flower means they often take nectar without causing pollination at all. On the other hand, ants may play another role in pollination ecology that is beneficial to the plant pollination system. Some plants produce nectar at extra floral nectaries, which may be situated so as to attract ants to the base of the flower, where they may discourage insects that would behave as nectar-robbers by piercing the corolla [115].

\section{Soil invertebrates and pollinators}

Some important flying pollinator groups nest in the soil or at the soil surface, including both social and solitary wasps and bees. Their role in the soil is purely as a nesting medium, and although they may actively burrow, their role as soil perturbators, is very much less than that of ants, for example (see section 'Scientific knowledge').

\section{Soil invertebrates, BCAs and pollinators}

There are relatively few examples of species that nest in the soil, and can act as both predators and pollinators. Some social and solitary wasps show all three behaviours, but even so, their importance as pollinators is likely to be relatively minor. Some parasitoids that pupate in the soil may also provide useful pollination services, e.g., Scoliidae, Bombyliidae and some Tachinidae. The ubiquitous ants, many of which nest in the soil, are probably the most important group that overlap all three areas, but even they are not usually important pollinators.

\section{Conclusion}

Of the interactions and overlaps introduced here, the one between soil invertebrates and BCAs is the most important, and further research is needed to evaluate the scope and impact of manipulation of the soil ecosystem to conserve or encourage beneficial BCAs.

\section{Conclusions and Key Gaps}

Our review has shown the critically important roles that invertebrates play in sustainable agriculture throughout the world. Although we have focused on invertebrates, we recognize that many of the functions of soil invertebrates are the result of combined activity with, or complementary activity by, microbial organisms, particularly fungi and bacteria. Manipulation of soil invertebrates for the benefit of agriculture will need to take into consideration the roles of these other groups of living organisms in soil. Similarly, the contribution of invertebrate BCAs is complemented by a range of fungi, bacteria, viruses and other microbial groups which also act as BCAs. There is not a similarly important microbial role in pollination services.

There is a great deal of anthropogenic change in the world and in the world's agriculture today and in the 
foreseeable future, of which climate change and land-use change are major current foci. Although these changes will affect agriculture directly through crop plants, there will also be substantial effects mediated by invertebrates in agricultural ecosystems, and these may be negative or positive. The better these contributions are understood, and the more options that can be used to effectively manipulate them, the more scope there will be to mitigate the impacts of these changes on agricultural production and food security.

Although we know a great deal about the services that invertebrates provide to agriculture, there are still great gaps in our knowledge that prevent their effective use or manipulation. Based on our review, we have identified several areas where we consider important gaps in knowledge need to be addressed in future priority setting and research.

\section{Scientific knowledge}

Improvement to knowledge and understanding of (i) wild pollinators of major crops, (ii) soil invertebrates, (iii) natural BCAs and (iv) their contribution to crop production in developed and developing countries. We found that the knowledge of the contribution of these unmanaged invertebrates to sustainable agriculture systems is generally lacking, particularly in developing countries.

Taxonomy and genetic characterization of invertebrates of agro-ecosystems, especially critical BCA and soil invertebrate faunal groups. We found that the biodiversity and taxonomic identity of soil invertebrate fauna are relatively unknown, and a sustained effort is required so that impacts of global anthropogenic change on this crucial biodiversity can be assessed.

\section{Conservation, use and access}

Rearing technologies to shift selected wild bees and other pollinator species to domestication, we found that for crops that are dependent on specialist pollinators, any change (whether due to climate change, land use change, agricultural intensification, etc.) is likely to have adverse effects on pollination services. Adapting and preserving these production systems will be dependent on the domestication and manipulation of their specialist pollinators.

Technologies and approaches to ensure the conservation and promotion of generalist natural enemies in agricultural landscapes through improved knowledge of landscape-level movement, and the effects of resources such as spatial and temporal refugia and alternative food sources.

The development of mass production methods for some important soil ecosystem engineers so as to facilitate experimental evaluation of their use in soil management practices.

\section{Facilitating policy environment}

An overarching holistic strategy that integrates invertebrates with the other ecosystem components better design and manage future agro-ecosystems for food security.

Guidelines for facilitating and regulating the movement of invertebrate genetic resources between countries, which build on what is so far available for BCAs and include emergency responses and pest risk assessment protocols. A coordinated development of standard protocols for pest risk assessment, e.g. ISPM2 [116] would facilitate survey and detection efforts and allow timely responses to new invasions. Similarly, responses to invasive pests will probably involve release of classical BCAs, and it may be appropriate to revisit ISPM3 in the context of emergency responses to new invasive threats.

Recognition that in implementing the Nagoya Protocol, countries need to take into consideration the need for invertebrate genetic resources to sustain agriculture, food production and world food security when drafting national strategies (e.g. producing guidelines and procedures).

Further development and implementation of existing AQ3 national biodiversity programmes. As noted above, the role and importance of invertebrate genetic resources diversity in relation to sustainable agricultural production is not well known, particularly in relation to soil invertebrates and pollinators in general, and in relation to some biological control invertebrates.

\section{Acknowledgements}

This review is based in part on a report that the authors prepared for the Commission on Genetic Resources for Agriculture (CGRFA at FAO, Rome) on climate change and invertebrate genetic resources for food and agriculture [117]. We thank Kim-Anh Tempelman and colleagues at the CGRFA for their interest, support and encouragement in preparing that report. We also thank Fabian Haas (icipe, Kenya) who contributed a case study as indicated; Joop van Lenteren (Wageningen University, The Netherlands) and several anonymous scientists of the CGRFA and FAO who reviewed parts of a draft of the report from which this review was derived; and Rebecca J. Murphy (United Kingdom) and Dafydd Pilling (FAO) for editorial inputs to that report.

\section{References}

1. Chauvel A, Grimaldi M, Barros E, Blanchart E, Desjardins T, Sarrazin M, et al. Pasture damage by an Amazonian earthworm. Nature 1999;398:32-3.

2. Decaëns $T$, Jiménez JJ, Lavelle P. Effect of exclusion of the anecic earthworm Martiodrilus carimaguensis Jiménez and Moreno on soil properties and plant growth in grasslands of the Eastern plains of Colombia. Pedobiologia 1999;43: 835-41. 
3. Lavelle P, Decaëns T, Aubert M, Barot S, Blouin M, Bureau F, et al. Soil invertebrates and ecosystem services. European Journal of Soil Biology 2006;42:3-15.

4. Wall DH, Fitter AH, Paul EA. Developing new perspectives from advances in soil biodiversity research. In: Bardgett RD, Usher MB, Hopkins DW, editors. Biological Diversity and Function in Soils. Cambridge University Press, Cambridge, UK; 2005. pp. 3-27.

5. Schaefer M. The soil fauna of a beech forest on limestone: trophic structure and energy budget. Oecologia 1990;82: 128-36.

6. Wall DH, Adams GA, Parsons AN. Soil biodiversity. In: Chapin FS, Sala OE, Huber-Sannwald E, editors. Global Biodiversity in a Changing Environment. Springer-Verlag, New York; 2001. pp. 47-82.

7. Decaëns T. Macroecological patterns in soil communities. Global Ecology and Biogeography 2010;19:287-302.

8. James SW, Porco D, Decaëns T, Richard B, Rougerie R, Erséus C. DNA barcoding reveals cryptic diversity in Lumbricus terrestris L., 1758 (Clitellata): resurrection of $L$. herculeus (Savigny, 1826). PLoS ONE 2010;5(12): e15629, 8 pp.

9. Weiher E, Keddy PA. Assembly rules as general constraints on community composition. In: Weiher E, Keddy PA, editors. Ecological Assembly Rules. Perspectives, Advances, Retreats. Cambridge University Press, Cambridge, UK; 1999. pp. 251-71.

10. Belyea LR, Lancaster J. Assembly rules within a contingent ecology. Oikos 1999;86:402-16.

11. Swift MJ, Heal OW, Anderson JM. Decomposition in Terrestrial Ecosystems. Blackwell Scientific, Oxford, UK; 1979. $372 \mathrm{pp}$.

12. Lavelle P, Bignell D, Austen M, Brown V, Behan-Pelletier VM, Garey J, et al. Connecting soil and sediment biodiversity: the role of scale and implication for management. In: Wall $\mathrm{DH}$, editor. Sustaining Biodiversity and Ecosystem Services in Soil and Sediments. Island Press, Washington, DC; 2004. pp. 193-224.

13. Wolters V. Biodiversity of soil animals and its function. European Journal of Soil Biology 2001;37:221-7.

14. Wolters V, Schaefer M. Effects of acid deposition on soil organisms and decomposition processes. In: Godbold DL, Hüttermann A, editors. Effects of Acid Rain on Forest Processes. Wiley, New York; 1994. pp. 83-127.

15. Decaëns T, Jiménez JJ, Gioia C, Measey GJ, Lavelle P. The values of soil animals for conservation biology. European Journal of Soil Biology 2006;42:S23-38.

16. Lavelle P. Faunal activities and soil processes: adaptive strategies that determine ecosystem function. Advances in Ecological Research 1997;27:93-132.

17. Coûteaux MM, Mousseau $M$, Célérier ML, Bottner $P$. Increased atmospheric $\mathrm{CO}_{2}$ and litter quality: decomposition of sweet chestnut leaf with animal food webs of different complexities. Oikos 1991;61:54-64.

18. Jones CG, Lawton JH, Shachak M. Organisms as ecosystem engineers. Oikos 1994;69:373-86.

19. Anderson JM. Soil organisms as engineers: microsite modulation of macroscale processes. In: Jones CG, Lawton $\mathrm{JH}$, editors. Linking Species and Ecosystems. Chapman and Hall, London, UK; 1995. pp. 94-106.
20. Brussaard L. Soil fauna, guilds, functional groups and ecosystem processes. Applied Soil Ecology 1998;9:123-35.

21. Lavelle $P$, Blanchart E, Martin A, Martin S, Spain A, Toutain $\mathrm{F}$, et al. A hierarchical model for decomposition in terrestrial ecosystems: application to soils of the humid tropics. Biotropica 1993;25:130-50.

22. Allen TFH, Hoekstra TW. Toward a Unified Ecology. Columbia University Press, New York; 1992. 384 pp.

23. Swift MJ, Vandermeer J, Ramakrishnan PS, Anderson JM, Ong CK, Hawkins BA. Biodiversity and agroecosystem function. In: Mooney JH, Medina HA, Sala EO, Schulze ED, editors. Functional Roles of Biodiversity: a Global Perspective. John Wiley and Sons, Chichester, UK; 1996. pp. 261-98.

24. Decaëns T, Jiménez JJ. Earthworm communities under an agricultural intensification gradient in Colombia. Plant and Soil 2002;240:133-43.

25. Lavelle P, Pashanasi B. Soil macrofauna and land management in Peruvian Amazonia (Yurimaguas, Loreto). Pedobiologia 1989;33:283-409.

26. Fragoso C, Lavelle P. Earthworm communities of tropical rain forests. Soil Biology and Biochemistry 1992;24:1397-408.

27. Jiménez JJ, Moreno AG, Decaëns T, Lavelle P, Fisher MJ, Thomas RJ. Earthworm communities in native savannas and man-made pastures of the eastern plains of Colombia. Biology and Fertility of Soils 1998;28:101-10.

28. Hendrix PF, Crossley DA Jr, Blair JM, Coleman DC. Soil biota as components of sustainable agroecosystems. In: Edwards CA, Lal R, Madden P, Miller RH, House G, editors. Sustainable Agricultural Systems. Soil and Water Conservation Society, Ankeny, lowa; 1990. pp. 637-54.

29. Jiménez JJ, Thomas RJ (editors). Soil Macroinvertebrate Communities in the Neotropical Savannas of Colombia. CIAT Publication No. 324. Centro Internacional de Agricultura Tropical, Cali, Colombia; 2001. 389 pp.

30. Blanchart E, Albrecht A, Alegre J, Duboisset A, Gilot C, Pashanasi B, et al. Earthworm communities of tropical agroecosystems: origin, structure and influence of management practices. In: Lavelle $\mathrm{P}$, Brussaard L, Hendrix PF, editors. Earthworm Management in Tropical Agroecosystems. CABI, Wallingford, UK; 1999. pp. 149-72.

31. Eschenbrenner V. Contribution des termites à la microagrégation des sols tropicaux. Cahier ORSTOM, Série Pedologie 1986;22:397-408.

32. Lilienfein J, Wilcke W, Ayarza MA, Lima SDC, Vilela L, Zech W. Annual course of matric potential in differently used savanna oxisols in Brazil. Soil Science Society of America Journal 1999:63:1778-85.

33. Coleman DC. The impacts of acid deposition on soil biota and C cycling. Environmental and Experimental Botany 1983;23:225-33.

34. Clarholm M. Heterotrophic, free-living protozoa: neglected organisms with an important task in regulating bacterial populations. In: Klug MJ, Reddy CA, editors. Current Perspectives in Microbial Ecology. American Society for Microbiology, Washington, DC; 1984. pp. 321-6.

35. Hamilton EW, Frank DA. Plant defoliation promotes microbial nitrogen cycling through increased root exudation of carbon. Ecology 2001;82:2397-402. 
36. Osler GHR, Sommerkorn M. Toward a complete soil $\mathrm{C}$ and $\mathrm{N}$ cycle: incorporating the soil fauna. Ecology 2007;88: 1611-21.

37. Wardle DA, Bardgett RD, Klironomos JN, Setälä $\mathrm{H}$, Van der Putten WH, Wall DH. Ecological linkages between aboveground and belowground biota. Science 2004;304:1629-33.

38. Treonis AM, Grayston SJ, Murray PJ, Dawson LA. Effects of root feeding, cranefly larvae on soil microorganisms and the composition of rhizosphere solutions collected from grassland plants. Applied Soil Ecology 2005;28:203-15.

39. Bardgett RD, Denton CS, Cook R. Below-ground herbivory promotes soil nutrient transfer and root growth in grassland. Ecology Letters 1999;2:357-60.

40. Lavelle P, Blanchart E, Martin A, Spain AV, Martin S. Impact of soil fauna on the properties of soils in the humid tropics. In: Segoe S, editor. Myths and Science in Soils of the Tropics. Soil Science Society of America, Madison, USA; 1992. pp. $157-85$.

41. Lavelle P, Spain AV. Soil Ecology. Kluwer Academic Publishers, Dordrecht, The Netherlands; 2001. 654 pp.

42. Wardle DA. Communities and Ecosystems - Linking the Aboveground and Belowground Components. Princeton University Press, Princeton, NJ; 2002. 400 pp.

43. Senapati BK, Lavelle P, Giri S, Pashanasi B, Alegre J, Decaëns $T$, et al. In-soil earthworm technologies for tropical agroecosystems. In: Lavelle P, Brussaard L, Hendrix PF, editors. Earthworm Management in Tropical Agroecosystems. CAB International, Wallingford, UK; 1999. pp. 199-237.

44. Lavelle $\mathrm{P}$, Brussaard L, Hendrix $\mathrm{P}$, editors. Earthworm Management in Tropical Agroecosystems. CABI Publishing, Wallingford, UK; 1999. 300 pp.

45. Costanza R, d'Arge R, de Groot R, Farberk S, Grasso M, Hannon B, et al. The value of the world's ecosystem services and natural capital. Nature 1997;387:253-60.

46. MEA (Millennium Ecosystem Assessment). Ecosystems and Human Well-Being: Current State and Trends. Island Press, Washington, DC; 2005. 917 pp. Available from: URL: http:// www.maweb.org/en/Condition.aspx

47. Davis DW, McMurtry JA. Introduction. In: Davis DW, Hoyt SC, McMurtry JA, AliNiazee MT, editors. Biological Control and Insect Pest Management. University of California, Division of Agricultural Sciences, Publication 4096. University of California Press, Oakland, Califonia; 1979. pp. i-ii.

48. Losey JE, Vaughan M. The economic value of ecological services provided by insects. BioScience 2006;56:311-23.

49. Barbosa P, editor. Conservation Biological Control. Academic Press, London, UK; 1998. 396 pp.

50. Letourneau D. Conservation biology: lessons for conserving natural enemies. In: Barbosa P, editor. Conservation Biological Control. Academic Press, London, UK; 1998. $396 \mathrm{pp}$.

51. van Lenteren JC. Internet Book of Biological Control. International Organization for Biological Control, Wageningen, The Netherlands; 2007. Available from: URL: http://www.IOBC-Global.org

52. Hunt EJ, Kuhlmann U, Sheppard A, Qin T-K, Barratt BIP Harrison L, et al. Review of invertebrate biological control agent regulation in Australia, New Zealand, Canada and the
USA: recommendations for a harmonized European system. Journal of Applied Entomology 2008;132:89-123.

53. IPPC. Guidelines for the Export, Shipment, Import and Release of Biological Control Agents and Other Beneficial Organisms. International Standards for Phytosanitary Measures No. 3. FAO, Rome, Italy; 2005. 32 pp. Available from: URL: http://www.ippc.int/file_uploaded/ 1146657660135 ISPM3.pdf

54. UN (United Nations). Nagoya Protocol on Access to Genetic Resources and the Fair and Equitable Sharing of Benefits Arising from their Utilization to the Convention on Biological Diversity. 2010. Available from: URL: http://treaties.un.org/ doc/source/signature/2010/Ch-XXVII-8-b.pdf

55. Cock MJW, van Lenteren JC, Brodeur J, Barratt BIP, Bigler F, Bolckmans $\mathrm{K}$, et al. Do new access and benefit sharing procedures under the Convention on Biological Diversity threaten the future of biological control? BioControl 2010;55:199-218.

56. Smith MA, Woodley NE, Janzen DH, Hallwachs W, Hebert PDN. DNA barcodes reveal cryptic host-specificity within the presumed polyphagous members of a genus of parasitoid flies (Diptera: Tachinidae). Proceedings of the National Academy of Sciences USA 2006;103(10):3657-62.

57. Smith MA, Wood DM, Janzen DH, Hallwachs W, Hebert PDN. DNA barcodes affirm that 16 species of apparently generalist tropical parasitoid flies (Diptera, Tachinidae) are not all generalists. Proceedings of the National Academy of Sciences USA 2007;104(12):4967-72.

58. Smith MA, Rodriguez JJ, Whitfield JB, Deans AR, Janzen $\mathrm{DH}$, Hallwachs W, et al. Extreme diversity of tropical parasitoid wasps exposed by iterative integration of natural history, DNA barcoding, morphology, and collections. Proceedings of the National Academy of Sciences USA 2008;105:12359-64.

59. Kabaluk JT, Svircev AM, Goettel MS, Woo SG, editors. The Use and Regulation of Microbial Pesticides in Representative Jurisdictions Worldwide. International Organisation for Biological Control of Noxious Animals and Plants; 2010. 99 pp. Available from: URL: http://www.iobcglobal.org/downlaod/ Microbial_Regulation_Book_Kabaluk_et_\%20al_2010.pdf

60. Smith EG, De Clerck-Floate RA, Van Hezewijk BH, Moyer JR, Pavlik E. Costs of mass-producing the root weevil, Mogulones cruciger, a biological control agent for houndstongue (Cynoglossum officinale L.). Biological Control 2009;48:281-6.

61. Cock M.J.W., van Lenteren JC, Brodeur J, Barratt BIP, Bigler $\mathrm{F}$, Bolckmans $\mathrm{K}$, et al. The use and exchange of biological control agents for food and agriculture. Background Study Paper No. 47. Commission on Genetic Resources for Food and Agriculture, FAO, Rome, Italy; 2009. 88 pp. Available from: URL: ftp.fao.org/docrep/fao/meeting/017/ ak569e.pdf

62. van Lenteren JC, Bueno VHP. Augmentative biological control of arthropods in Latin America. BioControl 2003;48:123-39.

63. Bale JS, van Lenteren JC, Bigler F. Biological control and sustainable food production. Philosophical Transactions of the Royal Society B: Biological Sciences 2008;363:761-76.

64. van Lenteren JC. The area under biological control and IPM in greenhouses is much larger than we thought. Sting 2006;29:7. 
65. Pilkington LJ, Messelink G, van Lenteren JC, Le Mottee K. 'Protected Biological Control' - biological pest management in the greenhouse industry. Biological Control 2010;52: 216-20.

66. Faegri K, van der Pijl L. The Principles of Pollination Ecology. Pergamon Press, Oxford, UK; 1979. 242 pp.

67. Kevan PG. Pollinators as bioindicators of the state of the environment: species, activity and diversity. Agriculture, Ecosystems and Environment 1999;74:373-93.

68. Buchmann SE, Nabhan GP. The Forgotten Pollinators. Island Press, Washington, DC; 1996. 312 pp.

69. Free JB. Insect Pollination of Crops. Academic Press, London, UK; 1993. 684 pp.

70. Klein AM, Vaissière BE, Cane J, Steffan-Dewenter I, Cunningham SA, Kremen $\mathrm{C}$, et al. Importance of pollinators in changing landscapes for world crops. Proceedings of the Royal Society B: Biological Sciences 2007;274:303-13.

71. Aizen MA, Garibaldi LA, Cunningham SA, Klein AM. How much does agriculture depend on pollinators? Lessons from long-term trends in crop production. Annals of Botany 2009;103:1579-88.

72. Gallai N, Salles JM, Settele J, Vaissière BE. Economic valuation of the vulnerability of world agriculture confronted with pollinator decline. Ecological Economics 2009;68: 810-21.

73. Allsopp $\mathrm{MH}$, de Lange WJ, Veldtman R. Valuing insect pollination services with cost of replacement. PLoS ONE 2008;3(9):e3128, 8 pp.

74. Sumner DA, Boriss $\mathrm{H}$. Bee-conomics and the leap in pollination fees. Agricultural and Resource Economics Update 2006;9(3). Giannini Foundation for Agricultural Economics, University of California; 2006. 11 pp. Available from: URL: www.agecon.ucdavis.edu/uploads/ update_articles/v9n3_3.pdf

75. Aizen MA, Harder LD. The global stock of domesticated honey bees is growing slower than agricultural demand for pollination. Current Biology 2009;19:1-4.

76. Hoehn P, Tscharntke T, Tylianakis JM, Steffan-Dewenter I. Functional group diversity of bee pollinators increases crop yield. Proceedings of the Royal Society B: Biological Sciences 2008;275:2283-91.

77. Winfree R, Kremen C. Are ecosystem services stabilized by differences among species? A test using crop pollination. Proceedings of the Royal Society B: Biological Sciences 2009;276:229-37.

78. Greenleaf SS, Kremen C. Wild bees enhance honey bees' pollination of hybrid sunflower. Proceedings of the National Academy of Sciences USA 2006;103:13890-95.

79. Rasmont $P$, Pauly A, Terzo M, Patiny S, Michez D, Iserbyt S, et al. The Survey of Wild Bees (Hymenoptera, Apoidea) in Belgium and France. FAO, Rome, Italy; 2005. 18 pp.

80. Biesmeijer JC, Roberts SPM, Reemer M, Ohlemuller R, Edwards M, Peeters $\mathrm{T}$, et al. Parallel declines in pollinators and insect-pollinated plants in Britain and the Netherlands. Science 2006;313:351-4.

81. NRC (National Research Council). Status of Pollinators in North America. National Research Council, Committee on the Status of Pollinators in North America. The National Academies Press, Washington, DC; 2007. 322 pp.
82. Cameron SA, Lozier JD, Strange JP, Koch JP, Cordes N, Solter LF, et al. Patterns of widespread decline in North American bumble bees. Proceedings of the National Academy of Sciences USA 2011;108:662-7.

83. Potts SG, Biesmeijer JC, Kremen C, Neumann P, Schweiger O, Kunin WE. Global pollinator declines: trends, impacts and drivers. Trends in Ecology and Evolution 2010a;25:345-53.

84. Kleijn D, Raemakers I. A retrospective analysis of pollen host plant use by stable and declining bumblebee species. Ecology 2008;89:1811-23.

85. Kevan PG, Greco CF, Belaoussoff S. Log-normality of biodiversity and abundance in diagnosis and measuring of ecosystemic health: pesticide stress on pollinators on blueberry heaths. Journal of Applied Ecology 1997;34: 1122-36.

86. Brittain CA, Bommarco R, Vighi M, Barmaz S, Settele J, Potts SG. The impact of an insecticide on insect flower visitation and pollination in an agricultural landscape. Agricultural and Forest Entomology 2010;12:259-66.

87. Bommarco R, Biesmeijer JC, Meyer B, Potts SG, Pöyry J, Roberts SPM, et al. Dispersal capacity and diet breadth modify the response of wild bees to habitat loss. Proceedings of the Royal Society B: Biological Sciences 2010;277: 2075-82.

88. Neumann P, Carreck C. Honey bee colony losses: a global perspective. Journal of Apicultural Research 2010;49:1-6.

89. Williams $\mathrm{PH}$, Araújo MB, Rasmont P. Can vulnerability among British bumblebee (Bombus) species be explained by niche position and breadth? Biological Conservation 2007;138:493-505.

90. Dormann CF, Schweiger O, Arens P, Augenstein I, Aviron S, Bailey D, et al. Prediction uncertainty of environmental change effects on temperate European biodiversity. Ecology Letters 2008;11:235-44.

91. van Engelsdorp D, Hayes J Jr., Underwood RM, Pettis J. A survey of honey bee colony losses in the U.S., Fall 2007 to Spring 2008. PLoS ONE 2008;3(12):e4071, 6 pp.

92. Potts SG, Roberts SPM, Dean R, Marris G, Brown MA, Jones $\mathrm{R}$, et al. Declines of managed honeybees and beekeepers in Europe? Journal of Apicultural Research 2010b;49:15-22.

93. Kraus B, Page RE. Effect of Varroa jacobsoni (Mesostigmata: Varroidae) on feral Apis mellifera (Hymenoptera: Apidae) in California. Environmental Entomology 1995;24:1473-80.

94. Moritz RFA, Kraus FB, Kryger P, Crewe RM. The size of wild honeybee populations (Apis mellifera) and its implications for the conservation of honeybees. Journal of Insect Conservation 2007;11:391-7.

95. Jaffé R, Dietemann V, Allsopp MH, Costa C, Crewe RM, Dall'olio $R$, et al. Estimating the density of honeybee colonies across their natural range to fill the gap in pollinator decline censuses. Conservation Biology 2010;24:583-93.

96. Folgarait $P$. Ant biodiversity and its relationship to ecosystem functioning: a review. Biodiversity and Conservation 1998;7:1221-44.

97. Sanders D, Van Veen FJF. Ecosystem engineering and predation: the multi-trophic impact of two ant species. Journal of Animal Ecology 2011;80(3):569-76.

98. Lovei GL, Sunderland KD. Ecology and behavior of ground beetles (Coleoptera: Carabidae). Annual Review of Entomology 1996;41:231-56. 
99. Luck RF, Shepard BM, Kenmore PE. Experimental methods for evaluating arthropod natural enemies. Annual Review of Entomology 1988;33:367-89.

100. Fabre J-H. More Hunting Wasps. Translated by Teixeira de Mattos, A. Dodd, Mead and Co., New York; 1921. 376 pp. [Originally published (1891) Souvenirs Entomologiques (Troisième série). Ed. Ch. Delagrave, Paris; 1921. $434 \mathrm{pp}$.]

101. Logan DP. Insect parasites of scarabs from sugarcane fields in southern Queensland (Coleoptera: Scarabaeidae). Australian Journal of Entomology 1999;38(4):382-4.

102. Heath A. Cluster fly, Pollenia rudis (Fabricius) and P. pseudorudis Rognes (Diptera: Calliphoridae). In: Capinera JL, editor. Encyclopedia of Entomology. 2nd ed. Springer, Dordrecht, The Netherlands; 2008. p. $932-5$.

103. Andreassen LD, Kuhlmann U, Mason PG, Holliday NJ. Classical biological control of the cabbage root fly, Delia radicum, in Canadian canola: an analysis of research needs. CAB Reviews: Perspectives in Agriculture, Veterinary Science, Nutrition and Natural Resources 2007;2(86):13.

104. van den Berg H, Cock MJW, Oduor GI. Natural control of Helicoverpa armigera in sunflower: assessment of the role of predation. Biocontrol Science and Technology 1997;7: 613-29.

105. Gange AC, Brown VK. Effects of root herbivory by an insect on a foliar-feeding species, mediated through changes in the host plant. Oecologia 1989;81:38-42.

106. Wurst S, Jones TH. Indirect effects of earthworms (Aporrectodea caliginosa) on an above-ground tritrophic interaction. Pedobiologia 2003;47:91-7.

107. González Megías A, Müller C. Root herbivores and detritivores shape above-ground multitrophic assemblage through plant-mediated effects. Journal of Animal Ecology 2010;79:923-31.

108. Soler R, Bezemer TM, Van Der Putten WH, Vet LEM, Harvey JA. Root herbivore effects on above-ground herbivore, parasitoid and hyperparasitoid performance via changes in plant quality. Journal of Animal Ecology 2005; 74:1121-30.

109. Rasmann S, Köllner TG, Degenhardt J, Hiltpold I, Toepfer S, Kuhlmann $\mathrm{U}$, et al. Recruitment of entomopathogenic nematodes by insect-damaged maize roots. Nature 2005;434:732-7.

110. Johnson SN, Staley JT, McLeod FAL, Hartley SE. Plant-mediated effects of soil invertebrates and summer drought on above-ground multitrophic interactions. Journal of Ecology 2011;99(1):57-65.

111. Wurst S, Forstreuter M. Colonization of Tanacetum vulgare by aphids is reduced by earthworms. Entomologia Experimentalis et Applicata 2010;137(1):86-92.

112. Birkhofer K, Bezemer TM, Bloem J, Bonkowski M, Christensen S, Dubois D, et al. Long-term organic farming fosters below and aboveground biota: implications for soil quality, biological control and productivity. Soil Biology and Biochemistry 2008;40(9):2297-308.

113. Lundgren JG. Relationships of Natural Enemies and Non-Prey Foods. Springer, Dordrecht, The Netherlands; 2009. $453 \mathrm{pp}$
114. Willmer P. Pollination and Floral Ecology. Princeton University Press, Princeton, NJ; 2011. 778 pp.

115. Proctor M, Yeo P. The Pollination of Flowers. Collins, London; 1973. 418 pp.

116. IPPC. Framework for Pest Risk Analysis. International Standards for Phytosanitary Measures No. 2. FAO, Rome, Italy; 2007. 15 pp. Available from: URL: https://www.ippc.int/ file_uploaded/1179929048771_ISPM02_2007_E.pdf

117. Cock MJW, Biesmeijer JC, Cannon RJC, Gerard PJ, Gillespie D, Jiménez JJ, et al. Climate Change and Invertebrate Genetic Resources for Food and Agriculture: State of Knowledge, Risks and Opportunities. Commission on Genetic Resources for Food and Agriculture, Background Study Paper No. 54. FAO, Rome; 2011. 105 pp. Available from: URL: http://www.fao.org/docrep/meeting/022/ mb390e.pdf

\section{Case Studies}

\section{Case study 1. Rehabilitation of degraded soils by triggering soil invertebrate activities in Africa}

In the Sahel, the 'zaï' is a traditional soil and water conservation (SWC) technique developed in the semiarid lands (yearly average rainfall $<600 \mathrm{~mm}$ ) in northern Burkina Faso (Yatenga Province), where the soils are heavily encrusted. The zaï is usually a hole or basin with a diameter of $20-30 \mathrm{~cm}$ and depth of $10-15 \mathrm{~cm}$ set at intervals of 1-5 m, with between 12000 and 15000 holes per hectare; part of the soil that has been removed is combined with organic matter and put back into the hole. The holes are above all used to rehabilitate the lateritic and sandy-clay soils that the Mossi call 'zippelle' ('clearing' or 'bare soil') and are dug during the dry season (November to May). Subsequently, seeds of crops or whole crop plants are placed in the zaï. The incorporation of organic matter increases the nutrient status of the soil. Runoff from the crusted soils will tend to infiltrate into the depressions, which consequently become microsites of greater soil water content.

During the dry season the zaïs collect the leaves, twigs and fine sand carried by the wind. In addition, organic mulch is placed in the holes by farmers in order to trigger termite activity; the termites dig underground galleries that facilitate deep infiltration of rainwater and runoff. Termites improve the structure of crusted soils by reducing soil compaction, increasing soil porosity and improving water infiltration. A study showed that this termite disturbance resulted in a viable management option and improved growth and yield of crops. Yields reached one tonne per hectare where cow manure had been added and termites were present.

Another agricultural technique used in a number of tropical countries in Africa to ameliorate soil conditions for crops is 'ecobuage'. This is a traditional complex agricultural system, more evolved than the slash-and-burn technique that entails incinerating herbaceous vegetation 
piled up in mounds and buried under a layer of soil taken from the surroundings. The technique supplies the soil with mineral nutrients through slashes, and increases soil $\mathrm{pH}$. In a study conducted in Bouenza (Congo), the use of 'maalas' (ecobuage) increased soil invertebrate communities, especially earthworms, which led to improved soil structural stability, creating good conditions for plant root development.

Prepared by Juan J. Jiménez

Sources:

Camacho N, Lavelle P, Jiménez JJ. Soil Macrofauna Field Manual. Technical Level. Food and Agricultural Organization of the UN (FAO), Special Publication; 2008. 100 pp.

Mando A, Brussaard L, Stroosnijder L. Termite- and mulch-mediated rehabilitation of vegetation on crusted soil in West Africa. Restoration Ecology 1999;7:33-41.

Mboukou-Kimbatsa I. Les Macroinvertébrés du Sol dans Différents Systèmes d'Agriculture au Congo: Cas Particulier de Deux Systèmes Traditionnels (Écobuage et Brûlis) dans La Vallée du Niari [Thèse de doctorat]. Université de Paris VI, Pierre et Marie-Curie, Paris; 1997. 163 Pp.

Ouedraogo M, Kaboré V. The 'zai': a traditional technique for the rehabilitation of degraded land in the Yatenga, Burkina Faso. In Reij C, Scoones I, Toulmin C, editors. Sustaining the Soil. Indigenous Soil and Water Conservation in Africa. Earthscan, London, UK; 1996. p. 80-92.

\section{Case study 2. Beetle banks for conservation of generalist predatory beetles}

Conservation of biological control need not be extensive or complicated. The application of 'beetle banks' in row crops is a case in point. Generalist predatory beetles in the families Carabidae and Staphylinidae (ground beetles and rove beetles, respectively), are key predators of arthropods in several cropping systems. They are longlived and highly mobile. Both adults and larvae are predatory. Shelter and alternative food are key habitat components for these beetles. Shelter provides hiding places for the mainly nocturnal beetles, and a refuge and source of alternative food during periods of disruption in crops (such as tilling or pesticide application). Shelter is essential during winter, when beetles must find protected, undisturbed sites. In small fields, beetles are able to invade from unmanaged edges. Field sizes have increased in modern agriculture, and the edges of fields cannot serve as a source of beetles for large acreages. Moreover, landuse patterns have changed, and unmanaged, grassy edges are not necessarily present.

Beetle banks provide a mechanism for conservation of population of these important BCAs, and for maintenance of the natural biological control ecosystem service. The banks are narrow strips of mixed grass species, planted within and on the margins of large fields. The grasses consist of native tussock species (grasses that form clumps) together with other grasses and herbs. These strips increase the abundance of predatory beetles within fields, and can result in substantially lower population of pests on crops. In addition to promoting predatory beetles, the beetle banks serve as conservation habitat for other predators, for example, wolf spiders, Paradosa spp. (Araneae: Lycosidae). Beetle banks also serve as habitat for ground-nesting birds, and as a source of prey for raptors and owls. Costs of establishment and maintenance are minimal. Management of invasive weeds in the grass strips is probably the only long-term management issue. Although there is a potential small loss of production by devoting farmland to these strips, long-term reduction of pest control costs would more than offset this loss.

Conclusions: Conservation habitat such as beetle banks can restore important natural biological control ecosystem services, and provide other conservation values in the maintenance of biodiversity in farm landscapes.

\section{Prepared by D. Gillespie}

\section{Sources:}

Collins KL, Boatman ND, Wilcox A, Holland JM, Chaney K. Influence of beetle banks on cereal aphid predation in winter wheat. Agriculture, Ecosystems and Environment 2002;93:337-50.

Collins KL, Boatman ND, Wilcox A, Holland JM. A 5-year comparison of overwintering polyphagous predator densities within a beetle bank and two conventional hedgebanks. Annals of Applied Biology 2003;143:63-71.

Hall CS. Grass Margins and Beetle Banks. SAC Technical Note T513R. Scottish Agricultural College, Edinburgh, UK; 2002. 2 pp. Available from: URL: http://www.sac.ac.uk/mainrep/pdfs/ tn513grassbeetles.pdf

\section{Case study 3. Saving millions of cassava smallholder farmers in Africa}

Cassava, yucca or manioc (Manihot esculenta; Euphorbiaceae) was introduced from South America into Africa by 
the Portuguese in the sixteenth century and today is a staple root crop for more than 200 million people in Africa alone. This major source of carbohydrates came under threat from a devastating pest, the cassava mealybug (Phenacoccus manihoti Matile-Ferrero; Hemiptera: Pseudococcidae).

The cassava mealybug was first recorded in Congo and Zaire (now the Democratic Republic of the Congo) in the early 1970s. It remains unclear how the mealybug crossed the Atlantic from its home range in South America to Africa, but increasing trade provided enough opportunity for transport even across large distances. Once in Africa, since there were no natural enemies to control it in its new habitat, the cassava mealybug quickly spread through the whole cassava growing area, causing cassava production to collapse.

In a combined effort involving IITA (International Institute of Tropical Agriculture), CABI, IAPSC (InterAfrican Phytosanitary Council) and other agencies, BCAs were found in three South American countries (Paraguay, Brazil and Bolivia) following extensive surveys. A parasitoid wasp Anagyrus lopezi (De Santis) (=Epidinocarsis lopezi) (Hymenoptera: Encyrtidae) was quarantined in the UK, shipped to Africa, mass reared and finally, after the local authorities granted permission, released in field trials. The operation was so successful that throughout sub-Saharan Africa cassava mealybug is now under complete control and no longer poses a threat to cassava production.

Besides the successful control of cassava mealybug, this joint effort led to close South-South and international cooperation and to a significant increase in the capacities in biological control and agricultural entomology in subSaharan Africa. Many African agricultural entomologists of that generation were educated through this programme. The programme cost, according to Swindale (1997), was about US $\$ 27$ million, while the benefits are estimated at US\$450 million!

The beneficiaries are the millions of cassava growing smallholders who - often unaware of the programme or the parasitoid wasp - enjoy the fruits of this work. Food security has been increased through improved harvests and health through reduced pesticide use, both of which would otherwise come at no cost to the smallholders, who nevertheless receive the full benefits for free.

Prepared by Fabian Haas, icipe (in Cock et al., 2009)

\section{Sources:}

Cock MJW, van Lenteren JC, Brodeur J, Barratt BIP, Bigler F, Bolckmans K, et al. The use and exchange of biological control agents for food and agriculture. Background Study Paper No. 47. Commission on Genetic Resources for Food and Agriculture, FAO, Rome, Italy; 2009. 88 pp. Available from: URL: ftp.fao.org/docrep/fao/meeting/017/ak569e.pdf
Neuenschwander P. Biological control of cassava and mango mealybugs in Africa. In: Neuenschwander $P$, Borgemeister C, Langewald J, editors. Biological Control in IPM Systems in Africa. CABI Publishing, Wallingford, UK; 2003. p. 45-59.

Swindale LD. The globalization of agricultural research: a case study of the control of the cassava mealybug in Africa. In: Bonte-Friedheim C, Sheridan K, editors. The Globalization of Science: the Place of Agricultural Research. ISNAR, The Hague, The Netherlands; 1997. p. 189-194.

Wikipedia; 2009. Cassava. Available from: URL: http:// en.wikipedia.org/wiki/Cassava

\section{Case study 4. Augmentative biological control of greenhouse whitefly on greenhouse crops}

Augmentative biological control of the greenhouse whitefly, Trialeurodes vaporariorum (Westwood) (Hemiptera: Aleyrodidae) is a keystone of the IPM system in greenhouse tomato production. Damage comes from honeydew exuded by nymphs and adults, which is a substrate for growth of sooty moulds that cover leaves and reduce photosynthesis, and from growth and yield reductions due to the removal of plant sap. In England in the mid-1920s, whitefly nymphs were found to be attacked and killed by the parasitoid Encarsia formosa (Gahan) (Hymenoptera: Aphelinidae). Both the greenhouse whitefly and $E$. formosa are probably indigenous to Mexico or Central America. In the 1920s and 1930s, $E$. formosa was produced in vast numbers and shipped around the world where it was released for control of greenhouse whitefly. The development of chemical insecticides in the 1940s resulted in the termination of this programme. Insecticide resistance in whitefly populations around the world prompted researchers and growers to resume biological control for greenhouse whiteflies in the late 1970s.

The majority of $E$. formosa used in biological control are produced by a few large companies, and are shipped nationally or internationally to customers. During shipping, the parasitoid is fragile and is sensitive to exposure to heat and cold and to shipping delays. This is the case for most augmentative biological control products. Delays in delivery can result in growers receiving a dead product and consequently experiencing difficulties establishing or maintaining successful biological control programmes. The product consists of cards with E. formosa pupae, which are placed into the crop every week through most of the cropping season. This ensures that parasitoids are present and hunting for hosts at all times. Other parasitoids may also be used, particularly Eretmocerus spp. (Hymenoptera: Aphelinidae), which are reportedly able to cope better 
with the hotter periods of the year. In some regions, predatory bugs, particularly omnivorous Miridae such as Macrolophus spp. or Dicyphus spp., are also introduced into the crop.

Conclusions: Modern augmentative biological control strategies involve the introduction of constructed food webs. These systems are built around mass-production capacity in a relatively few centres, are dependent on justin-time delivery strategies, and are sensitive to disruptions in transportation systems.

\section{Prepared by Dave Gillespie}

\section{Sources:}

Avilla J, Albajes R, Alomar O, Castañe C, Gabarra R. Biological control of whiteflies on vegetable crops. In: Heinz KM, Van Driesche RG, Parrella MP, editors. Biocontrol in Protected Culture. Ball Publishing, Batavia, Illinois; 2004. p. 171-84.

van Lenteren J. A greenhouse without pesticides: fact or fantasy? Crop Protection 2000;19:375-84.

van Lenteren JC, van Roermund HJW, Sütterlin S. Biological control of greenhouse whitefly (Trialeurodes vaporariorum) with the parasitoid Encarsia formosa: how does it work? Biological Control 1996;6:1-10.

\section{Case study 5. Generalist augmentative BCAs can prevent new pests disrupting IPM: South American tomato pinworm}

When IPM systems rely on natural or augmentative biological control, the introduction or spread of a new pest can disrupt that system, and cause farmers to turn to broad-spectrum insecticides for pest control. The invasion of the South American tomato pinworm, Tuta absoluta (Cameron) (Lepidoptera: Gelechiidae), from South America into the Mediterranean basin of Europe and North Africa in about 2006 had the potential to do just that. This pest attacks tomato, some related crop plants, such as aubergine (eggplant) and potato, and some solanaceaous weeds in South America, where it is indigenous. On tomato, it mines in the fruit, causing fruit rot and rendering fruit unmarketable. The IPM system in protected culture of tomato in the Mediterranean area is largely based on the release of BCAs. Broad-spectrum insecticides are rarely used and it is possible to produce a crop without such intervention. With the introduction of T. absoluta, this IPM system was expected to be disrupted.

Although some knowledge of the biology and efficacy of the natural enemies of $T$. absoluta is available in South America, time and much additional research would have been needed to develop the knowledge required to make introduction of these species to Europe. Up until now, access to these potentially useful BCAs has been blocked by unresolved benefit-sharing considerations in South America. European researchers and biological control companies responded with intensive investigations of the impact of existing augmentative BCAs on T. absoluta and identified species that could be used to manage this pest. This will help to buffer the tomato industry against disruption of its augmentative biological control programmes, and in fact, has stimulated the uptake of augmentative biological control as a result of the high efficacy of one of the agents (K. Bolckmans and B.V. Koppert, personal communication, 2011). In the long term, a classical biological control solution may need to be implemented.

Conclusions: Although invasive pests can be highly disruptive to existing IPM programmes that are based on biological control, application or management of existing generalist BCAs may resolve this. Timely access to genetic resources used in biological control is essential for the sustainability of IPM programmes.

\section{Prepared by Dave Gillespie}

Sources:

Anon. Tuta absoluta. Data sheets on quarantine pests. EPPO Bulletin 2005;35:434-5.

Desneux N, Wajnberg E, Wyckhuys KAG, Burgio G, Arpaia S, Narváez-Vasquez CA, et al. Biological invasion of European tomato crops by Tuta absoluta: ecology, geographic expansion and prospects for biological control. Journal of Pest Science 2010;83:197-215.

Hassan MN, Alzaidi S. Tuta absoluta - a serious pest advancing in the Mediterranean region. Roll of pheromones in management strategies. International Pest Control 2009;51:85-7.

Urbaneja A, Montón H, Mollá O. Suitability of the tomato borer Tuta absoluta as prey for Macrolophus pygmaeus and Nesidiocoris tenuis. Journal of Applied Entomology 2009;133:292-6.

\section{Case study 6. The potato/tomato psyllid, Bactericera cockerelli, disrupts greenhouse IPM}

The potato/tomato psyllid, B. cockerelli (Sulc) (Hemiptera: Psyllidae) is a pest of tomato and potato in North America. It overwinters in the southern regions of the USA, and migrates northward annually, as temperatures become warmer, occasionally reaching Canada. Saliva injected into the tomato plant during feeding causes a 
physiological injury known as psyllid yellows. This is characterized by interveinal chlorosis, and is accompanied by a dramatic loss of growth and production. In mid-1996, B. cockerelli invaded tomato greenhouses in British Columbia, Canada. It spread rapidly to other greenhouses due to movement of equipment and personnel between sites. Its presence and the associated injury prompted growers to apply broad-spectrum pyrethroid, organophosphate and carbamate insecticides, which generated secondary outbreaks of greenhouse whiteflies (T. vaporariorum (Westwood); Hemiptera: Aleyrodidae) and twospotted spider mites (Tetranychus urticae Koch; Acari: Tetranychidae), because of the loss of the BCAs of these pests. At present, $B$. cockerelli continues to be invasive in greenhouses, although it is not present in every year, or in every greenhouse. Although an augmentative BCA was developed and tested in the tomato industry in Canada, the inconsistency in the need for this agent has made it expensive to produce and difficult to obtain. More recently, $B$. cockerelli has invaded New Zealand, where it is causing serious disruptions to the IPM programmes on protected tomatoes, and on potato crops.

Prepared by Dave Gillespie

Sources:

Gillespie DR. Paratrioza cockerelli (Sulc). Technical Report 132(R), Pacific Agri-Food Research Centre, Agassiz, British Columbia, Canada; 2000.

Knowlton GF, Janes MJ. Studies on the biology of Paratrioza cockerelli (Sulc.). Annals of the Entomological Society of America 1931;24:283-91.

Teulon DAJ, Workman PJ, Thomas KL, Nielsen MC. Bactericera cockerelli: incursion, dispersal and current distribution on vegetable crops in New Zealand. New Zealand Plant Protection 2009;62:136.

\section{Case study 7. Crop dependence on pollination}

About two-thirds of the major food crops used for human consumption across the world depend to some degree on pollination by insects. Klein et al. (2007) compiled published information on major crops and categorized them from 'insect pollination essential' to 'no increase with insects present'. Some of the important crops in each category include:

Essential: Watermelon, melon, pumpkin, squash, marrow (zucchini), kiwifruit, Annona reticulata L. (custard apple), pawpaw, passion fruit, Brazil nuts, macadamia, cocoa and vanilla.

High dependence on pollination: Cucumber, buckwheat, carambola, avocado, durian, plums, peaches, cherries (sweet and sour), apricot, apples, pears, mangoes, blackberries, raspberries, Solanum quitoense (naranjilla), blueberries, cranberries, almonds, cashew, turnip rape, kola nuts, Coriandrum sativum (coriander), Cuminum cyminum (cumin), cardamom, fennel (seed), nutmeg and allspice.

Modest dependence: Okra, aubergine (eggplant), guava, pomegranate, strawberries, black currant, red currant, chestnut, mustard (seed), rapeseed, coconut, soybean, cotton (seed), sunflower, sesame, faba beans (broad beans), Vitellaria paradoxa (shea nuts), coffee and caraway.

Little dependence: Pigeon peas, tomatoes, Phaseolus vulgaris (kidney beans), citrus fruits, rambutans, tamarind, groundnut (peanuts), oil palm, flax (seed), Capsicum (red pepper) and chillies.

No increase with insects present: Lentils, peas, grapes, olives, black pepper, Chenopodium quinoa (quinoa), chickpeas, wheat, barley, maize and other grain crops.

The insects responsible for crop pollination range from managed honeybees and bumblebees to solitary bees, dung flies, carrion flies, midges, moths and hoverflies. Many crops can be pollinated by managed honeybees as well as a range of wild pollinators. Other crops need specific groups of insects: cocoa is pollinated by ceratopogonid midges, pawpaw by carrion and dung flies, oil palm by a weevil and figs by fig wasps.

Information on pollination of many crops is still incomplete or even lacking completely. Crops have been moved across the world and in that process will certainly have lost old pollinator species and groups and picked up new ones. Movement of crops and habitat destruction has led to severe problems in crop pollination as well, for example, the need for hand pollination of vanilla in Madagascar (where it is not indigenous) and apple in China (where it is probably indigenous, but there are few native pollinators as a result of intensive land use).

Prepared by Koos Biesmeijer

Source:

Klein AM, Vaissière BE, Cane J, Steffan-Dewenter I, Cunningham SA, Kremen C, et al. Importance of pollinators in changing landscapes for world crops. Proceedings of the Royal Society B: Biological Sciences 2007;274:303-13.

\section{Case study 8. The million dollar oil palm pollinator weevil}

Up until the 1980s it was assumed that oil palms are wind-pollinated. However, pollination has never been a problem in West Africa, the original home of the commercial oil palm (Elaeis guineensis; Arecaceae), whereas in 
Malaysia, especially Sabah, assisted pollination was necessary and even then yields were lower than those in Africa.

In 1977, the Unilever Plantations Group started a research programme with the Commonwealth Institute of Biological Control. Dr R.A. Syed investigated the possibility that pollinating agents are involved in Cameroon. He found that both male and female flowers are attended by a complex of weevils (Curculionidae) of the subfamily, Derelominae, a group that is associated with palm flowers. The beetles breed in the flowers of both sexes and had been reported to cause damage.

Careful observations showed that weevils breeding in male flowers are all species now placed in the genus Elaeidobius, whereas those breeding in female flowers are Prosoestus spp. Elaeidobius spp. are attracted to male flowers only during anthesis when a strong aniseed-like scent is emitted. When the stigmas are receptive, the female flower emits short pulses of a similar but sharper and more penetrating odour which attracts Elaeidobius spp. away from the male flowers. On arrival in the female inflorescence, the beetles find no food and soon leave. Oviposition takes place after anthesis so that the larvae develop on tissue which has served its purpose and no longer has any function for the palm and therefore Elaeidobius spp. causes no significant damage. Syed went on to demonstrate that during the wet season, very little pollen is carried in the air and that if insects are excluded, pollination does not take place. The examination of Elaeidobius spp. showed that they become covered in pollen which is shed when they clamber about the female inflorescence. In all, there are six species of Elaeidobius in Cameroon. Each species is dominant in a different zone of each male flower spike, and each has slightly different climatic requirements so that the relative abundance of the species changes from the wet coastal zone to the drier interior. Thus, the six species are able to coexist on the same resource.

Elaeidobius kamerunicus was selected for Malaysian conditions and subjected to intensive screening tests using the protocols that had been developed for organisms to be used in biological weed control. The weevil was not attracted to or able to survive for long on the flowers of other palms, except for a limited extent on the South American oil palm (Elaeis oleijera). For importation into Malaysia, E. kamerunicus was bred in captivity on sterilized oil palm flowers, and carried in the pupal stage to Kuala Lumpur in individual glass tubes. En route, the contents were examined in the UK and repacked to ensure that no contaminants were inadvertently introduced along with the pollinator. These precautions were necessary to eliminate oil palm pathogens and natural enemies of E. kamerunicus, which is infested with mites and nematode larvae in Africa. Two releases were made in February 1981 and within a year, the weevil had spread throughout Peninsular Malaysia and was extremely abundant in all plantations. The weevils were taken to Sabah in March 1981, with even more impressive results. In the early 1980s they were also taken to Papua New Guinea, the Solomon Islands, Sumatra and Thailand, leading to successful establishment and enhanced yields. The introduction of E. kamerunicus into new isolated plantings of oil palm has become standard practice.

Oil palm fruit set in Malaysia now regularly reaches the levels found in Cameroon, hand pollination has been discontinued, and yields raised by about $20 \%$. Calculations indicated that, with the money saved on hand pollination, the introduction of the pollinator was worth some US\$115 million per year to the planters. This is the only example of a pollinator other than bees that has been deliberately introduced widely. The protocols to assess the risk of its introduction based on those used for the classical biological control of weeds proved satisfactory.

Prepared by Matthew J.W. Cock

Source:

Greathead DJ. The multi-million dollar weevil that pollinates oil palms. Antenna, Bulletin of the Royal Entomological Society of London 1983;7:105-107.

\section{Case study 9. The role of varroa mites in infections of Kashmir bee virus and deformed wing virus in honeybee}

Varroa mites (V. destructor Anderson and Trueman; Acari: Varroidae) have been blamed for the outbreaks of so-called parasitic mite syndrome, a condition with complicated and highly variable symptoms, in the western honeybee Apis mellifera L. (Hymenoptera: Apidae). Despite variability, all varroa-infested colonies have an unusual presence of diseased brood, which is often infected with one or more bee viruses. Although it is not clear how mites kill bee colonies, a general presumption is that varroa mites have a significant influence on virus infections of bees with the possibility of mites serving as vectors or activators of the viruses.

The varroa mite is the most serious pest of the honeybee known to date. The ectoparasitic mite $V$. destructor harms both brood and adult bees causing a disease called varroosis or parasitic mite syndrome and including a form of brood damage termed 'snotty brood'. From the beekeeping point of view there are thresholds for economic damage and for irreversible colony damage. At low infestation rates, clinical symptoms are not visible, and infestations often remain undetected. Moderate infestation rates reduce the growth of the honeybee population, and therefore, the honey yield. Gradual increase in the parasite population during autumn leads to greater loss of adult honeybees which, weakened by the impact of the mite, may die prematurely or fail to return to the hive because learning has been compromised. The final breakdown of a 
honeybee colony is associated with typical symptoms of parasitic mite syndrome such as scattered brood, crawling and crippled bees, superseding of queens, etc. Several reports confirm that under temperate conditions untreated colonies may collapse due to varroosis 3-4 years after the initial infestation. It is clear that mite population growth is lower in subtropical and tropical climates.

$V$. destructor is a vector for various honeybee viruses. So far, about 18 different viruses have been isolated from honeybees. For Kashmir bee virus (KBV), sacbrood virus, acute bee paralysis virus (ABPV), Israel acute paralysis virus (IAPV) and deformed wing virus (DWV), it has been proven that they can be vectored by $V$. destructor. In the absence of the mite, these viruses cause covert infections and have been considered a minor problem to honeybee health. Feeding activities of the mite increase levels of these viruses in individual bees by spreading the viral particles. Studies have also indicated that the mites activate viral replication and increase the virulence of the viruses, leading to overt diseases with which the weakened immune system of the bees is unable to cope.

Prepared by Suresh K. Raina

\section{Sources:}

Allen MF, Ball BV. The incidence and world distribution of the honey bee viruses. Bee World 1996;77:141-62.

Bowen-Walker PL, Martin SJ, Gunn SJ. The transmission of deformed wing virus between honeybees (Apis mellifera) by the ectoparasitic mite Varroa jacobsoni Oud. Journal of Invertebrate Pathology 1999;73:101-6.

Ghosh RC, Ball BV, Willcocks MM, Carter MJ. The nucleotide sequence of sacbrood virus of the honey bee: an insect picorna-like virus. Journal of General Virology 1999;80:1541-9.

Shen M, Yang X, Cox-Foster D, Cui L. The role of varroa mites in infections of Kashmir bee virus (KBV) and deformed wing virus (DWV) in honey bee. Virology 2005;342:141-9.

Shimanuki H, Knox DA. Bee health and international trade. Revue Scientifique et Technique Office International des Epizooties 1997;16:172-176.

\section{Case Study 10. Earthworms enhance plant tolerance to nematode infection through non-trophic effects of ecosystem engineering}

Below-ground interactions are complex and so far the mechanisms involved are not well known. Studies on the importance of non-trophic relationships, both above and below ground, are not abundant. Although agricultural practices that boost the development of earthworm communities in soil can be encouraged to enhance sustainability and to naturally alleviate nematode impact, the mechanisms are not well understood.

Plant-parasitic nematodes are serious pests that cause crop production losses and high economic damage; they may reduce global crop yields by up to $10 \%$ (Whitehead, 1997). Earthworms and vermicompost have been shown to reduce the harmful impact of nematode infestation in banana plantations, among others.

Soil nematode populations have been shown to be depressed in the presence of earthworms. The burrowing nematode Radopholus similis (Cobb) Thorne and the lesion nematodes Pratylenchus spp. are major constraints to banana cultivation worldwide. Studies on this crop have shown that earthworms help reduce the severity of root damage $(50 \%$ reduction of root necrosis in the presence of earthworms), although nematode densities do not change. Growth of banana plants and the concentration of certain elements in the soil can be positively influenced by the presence and activities of earthworms. The efficiency of the microbial community involved in phosphorous bioavailability can be enhanced by soil bioturbation carried out by the endogeic earthworm $P$. corethrurus (Müller). Increased phosphorous availability would lead to increased phosphorous uptake resulting in better plant nutrition and increased tolerance of plant-feeding nematodes.

The nematode Heterodera sacchari Luc and Merny (Heteroderidae) forms external cysts on rice roots leading to serious damage in upland rice fields in Africa. Blouin et al. (2005) demonstrated the effect of an earthworm (Millsonia anomala Omodeo; Megascolecidae) on the physiology of nematode-infested plants through selected stress-responsive genes coding for lipoxygenase, phospholipase $D$ and cysteine protease. The ability of plants to respond through physiological mechanisms was enhanced by earthworm presence. Decrease in rice growth caused by $H$. sacchari was suppressed in the presence of earthworms. Root biomass was not affected by nematodes when earthworms were present and the expression of stress-responsive genes in the leaves was modulated by below-ground activities.

Several likely mechanisms involved in earthworm/ nematode interactions of this type have been suggested, including ingestion of nematodes by earthworms leading to reduced nematode incidence and root damage, or the activation of bacteria antagonistic to plant parasitic nematodes by earthworms. However, the former hypothesis is inadequate as reduction of plant parasitic nematodes has also been observed in soil treated with commercial vermicompost.

Although the mechanisms involved are not clear, there seems to be several, potentially conflicting systemic effects of plant-parasitic nematodes and beneficial 
earthworms. These studies demonstrate that soil habitat transformation by bioturbating invertebrates bring changes to physical, chemical and biological properties that limit the damage of nematodes in some agricultural crops.

Prepared by Juan J. Jiménez and Patrick M. Lavelle

\section{Sources:}

Arancon NQ, Galvis P, Edwards C, Yardim E. The trophic diversity of nematodes communities in soil treated with vermicompost. Pedobiologia 2003;47:736-740.

Blouin M, Zuily-Fodil Y, Pham-Thi AT, Laffray D, Reversat G, Pando A, et al. Belowground organism activities affect plant aboveground phenotype, inducing plant tolerance to parasites. Ecology Letters 2005;8:202-8.

Brown GG, Pashanasi B, Villenave C, Patron JC, Senapati BK, Giri S, et al. Effects of earthworms on plant production in the tropics. In: Lavelle P, Brussaard $L$, Hendrix $P$, editors. The Management of
Earthworms in Tropical Agroecosystems. CAB International, Wallingford, UK; 1999. p. 87-148.

Dash MC, Senapati BK, Mishra CC. Nematode feeding by tropical earthworms. Oikos 1980;34:322-5.

Lafont A, Risède J-M, Loranger-Merciris G, Clermont-Dauphin C, Dorel M, Rhino B, et al. 2007. Effects of the earthworm Pontoscolex corethrurus on banana plants infected or not with the plant-parasitic nematode Radopholus similis. Pedobiologia 2007;51:311-8.

Loranger-Merciris G, Cabidoche Y-M, Deloné B, Quénéhervé $\mathrm{P}$, Ozier-Lafontaine $\mathrm{H}$. How earthworm activities affect banana plant response to nematodes parasitism. Applied Soil Ecology 2012;52:1-8.

Whitehead AG. Plant Nematode Control. CABI, Wallingford, UK; 1993. 384 pp.

Yeates GW. Soil nematode populations depressed in the presence of earthworms. Pedobiologia 1981;22:191-5.

\section{Author Queries:}

AQ1: Please specify the corresponding author and the e-mail ID.

AQ2: Please provide the expansion of EPNs.

AQ3: Please check the sentence 'Further development and implementation of existing ...' as the sense conveyed is incomplete, 